\title{
Plasticity of Signaling by Spinal Estrogen Receptor $\alpha$, $\kappa$-Opioid Receptor, and Metabotropic Glutamate Receptors over the Rat Reproductive Cycle Regulates Spinal Endomorphin 2 Antinociception: Relevance of Endogenous-Biased Agonism
}

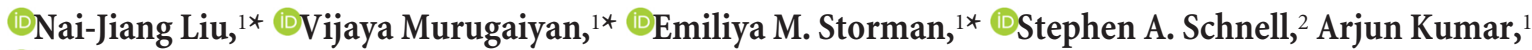 \\ -Martin W. Wessendorf, ${ }^{2}$ and Alan R. Gintzler ${ }^{1}$ \\ ${ }^{1}$ Department of Obstetrics and Gynecology, State University of New York, Downstate Medical Center, Brooklyn, New York 11203, and ${ }^{2}$ Department of \\ Neuroscience, School of Medicine, University of Minnesota, Minneapolis, Minnesota 55455
}

We previously showed that intrathecal application of endomorphin 2 [EM2; the highly specific endogenous $\mu$-opioid receptor (MOR) ligand] induces antinociception that varies with stage of the rat estrous cycle: minimal during diestrus and prominent during proestrus. Earlier studies, however, did not identify proestrus-activated signaling strategies that enable spinal EM2 antinociception. We now report that in female rats, increased spinal dynorphin release and $\kappa$-opioid receptor (KOR) signaling, as well as the emergence of glutamate-activated metabotropic glutamate receptor $1\left(\mathrm{mGluR}_{1}\right)$ signaling, are critical to the transition from an EM2 nonresponsive state (during diestrus) to an analgesically responsive state (during proestrus). Differential signaling by mGluR $_{1}$, depending on its activation by membrane estrogen receptor $\alpha$ ( $\mathrm{mER} \alpha$; during diestrus) versus glutamate (during proestrus), concomitant with the ebb and flow of spinal dynorphin/KOR signaling, functions as a switch, preventing or promoting, respectively, spinal EM2 antinociception. Importantly, EM2 and glutamate-containing varicosities appose spinal neurons that express MOR along with $\mathrm{mGluRs}$ and $\mathrm{mER} \alpha$, suggesting that signaling mechanisms regulating analgesic effectiveness of intrathecally applied EM2 also pertain to endogenous EM2. Regulation of spinal EM2 antinociception by both the nature of the endogenous $\mathrm{mGluR}_{1}$ activator (i.e., endogenous biased agonism at $\mathrm{mGluR}_{1}$ ) and changes in spinal dynorphin/KOR signaling represent a novel mechanism for modulating analgesic responsiveness to endogenous EM2 (and perhaps other opioids). This points the way for developing noncanonical pharmacological approaches to pain management by harnessing endogenous opioids for pain relief.

Key words: antinociception; biased agonism; dynorphin; endomorphin 2; estrous cycle; $\kappa$-opioid receptor

Significance Statement

The current prescription opioid abuse epidemic underscores the urgency to develop alternative pharmacotherapies for managing pain. We find that the magnitude of spinal endomorphin 2 (EM2) antinociception not only varies with stage of reproductive cycle, but is also differentially regulated during diestrus and proestrus. This finding highlights the need for sex-specific and cycle-specific approaches to pain management. Additionally, our finding that spinal EM2 antinociception in female rats is regulated by both the ebb and flow of spinal dynorphin/ $\kappa$-opioid receptor signaling over the estrous cycle, as well as the nature of the endogenous mGluR $_{1}$ activator, could encourage noncanonical pharmacological approaches to pain management, such as harnessing endogenous opioids for pain relief.

\section{Introduction}

Nociception and opioid antinociception are profoundly influenced by sex (Fillingim et al., 2009; Loyd and Murphy, 2014;
Maurer et al., 2016) and reproductive cycle (Mogil et al., 2000; Teepker et al., 2010; Ibironke and Aji, 2011). This is exemplified by our recent finding in rats that during proestrus, spinal endomorphin 2 (EM2) analgesic responsiveness is prominent (com- 
parable to males), whereas it is minimal during diestrus (Liu and Gintzler, 2013). Notably, diestrus corresponds to the time around menses, when women experience the greatest severity of many chronic pain conditions (e.g., fibromyalgia, migraine, temporomandibular joint pain; Hassan et al., 2014), suggesting that heightened nociception may be caused by compromised endogenous spinal EM2 antinociception.

Dependence of opioid antinociception on stage of reproductive cycle suggests a modulatory role for sex steroids, among which estrogens has been the most studied (Acosta-Martinez and Etgen, 2002; Micevych et al., 2003; Smith et al., 2006; Liu et al., 2011b; Gintzler and Liu, 2012; Kumar et al., 2015). Consistent with these reports, estrogen receptors (ERs) are extensively distributed throughout the CNS, in both spinal as well as supraspinal areas involved in nociception and opioid antinociception (Shughrue et al., 1997; Papka et al., 2001). The CNS also contains the enzyme aromatase, which provides the CNS with an intrinsic source of estrogens (Naftolin et al., 1996; Evrard and Balthazart, 2004; Hojo et al., 2004; Peterson et al., 2005; Evrard, 2006), which can be produced independent of the reproductive cycle. Notably, CNS aromatase is present in neuronal processes (Foidart et al., 1995; Naftolin et al., 1996; Horvath et al., 1997; Saldanha et al., 2000; Evrard et al., 2004), allowing locally synthesized estrogens to be released at synapses and activate ERs located on neuronal plasma membranes (Blaustein et al., 1992; McEwen and Alves, 1999; McEwen et al., 2001; Beyer et al., 2003). Membrane ERs (mERs) endow neuronally produced estrogens with neurotransmitter-like (also known as synaptocrine) attributes (Saldanha et al., 2011).

We recently described an additional, subcellular modality of neuronal estrogenic signaling that we term "oligocrine" (Liu et al., 2017). This modality is enabled by the oligomerization of aromatase with $\mathrm{mER} \alpha$ as well as the $\mu$-opioid receptor (MOR) and metabotropic glutamate receptor 1 ( $\mathrm{mGluR}_{1}$; Liu et al., 2017). The presence of these molecules in a common signaling complex enables the subcellular compartmentalization of estrogenic signaling, allowing it to be, at times, inversely related to circulating estrogen levels. For instance, during diestrus, when circulating estrogens are low, spinally synthesized estrogens actively suppress EM2 antinociception, whereas during proestrus, when circulating estrogens are elevated, spinal EM2 antinociception is no longer subjected to estrogenic suppression (Liu et al., 2017).

In the current study, we investigated whether the loss of spinal estrogenic suppression of intrathecal EM2 antinociception is sufficient for the emergence of spinal EM2 analgesic responsiveness during proestrus, or whether additional signaling strategies are also required. Since both dynorphin and $\kappa$-opioid receptor (KOR) activity are prerequisites for intrathecal EM2 antinociception in female rats (Liu and Gintzler, 2013), we investigated whether spinal dynorphin/KOR signaling varied over the estrous cycle and, if so, the relevance of this fluctuation to spinal EM2 analgesic responsiveness in diestrus versus proestrus. We also explored the relevance of $\mathrm{mGluR}_{1}$ (along with $\mathrm{mGluR}_{2 / 3}$ ) signaling to the proestrus-associated emergence of intrathecal EM2 antinociception. This was based on initial findings that, in contrast to diestrus (when $\mathrm{mGluR}_{1}$ signaling suppresses intrathecal $\mathrm{EM} 2$ antinociception), the activity of $\mathrm{mGluR}_{1}$ (along with $\mathrm{mGluR}_{2 / 3}$ ) is actually required for the intrathecal EM2 antinociception that emerges during proestrus.

Our findings revealed that the switch in spinal EM2 analgesic responsiveness over the reproductive cycle depends on the ebb and flow of dynorphin/KOR signaling and whether $\mathrm{mGluR}_{1}$ is activated by glutamate or $\mathrm{mER} \alpha$. Facilitative versus suppressive modulation of spinal EM2 antinociception by $\mathrm{mGluR}_{1}$ signaling that depends on the endogenous activator of $\mathrm{mGluR}_{1}$ most likely reflects endogenous-biased agonism—agonist-induced stabilization of receptor conformations that preferentially stimulate specific signaling pathways.

\section{Materials and Methods}

Experimental animals. We used female rats (Sprague Dawley, Charles River; 225-275 g), which were maintained in an approved controlled environment on a $12 \mathrm{~h}$ light/dark cycle. Food and water were available ad libitum. All experimental procedures were reviewed and approved by the Animal Care and Use Committees of the State University of New York Downstate Medical Center.

Determination of estrous cycle stage. Histology of vaginal smears was used to determine stage of estrous cycle. Predominance of small leukocytes was indicative of diestrus; predominance of large round nucleated cells indicated proestrus.

Implantation of intrathecal cannula. A permanent indwelling cannula [polyethylene (PE-10) tubing] was inserted into the lumbar spinal cord subarachnoid space under isoflurane anesthesia. In brief, a saline-filled PE-10 catheter was inserted through an incision in the atlanto-occipital membrane, slowly introduced into the spinal cord subarachnoid space $(8.0 \mathrm{~cm})$, and secured in place. The cephalic portion of each catheter was externalized through the skin above the skull area, where it was relatively inaccessible to the paws. Only animals that appeared to be free of infection upon gross inspection were used. Motor integrity was assessed in all experimental groups by using the righting reflex and the inclined plane test. Those exhibiting motor impairment following surgery were eliminated from the study. All experiments were initiated 1 week after surgery and completed $<2$ weeks after surgery. To eliminate any possibility that surgery confounded data interpretation by disrupting the estrous cycle, diestrus and proestrus were defined by vaginal smear histology, rather than predictions that assumed regularity of cycling.

In vivo perfusion of spinal intrathecal space and quantification of dynorphin release. We implanted two PE- 10 catheters $(8.25 \mathrm{~cm}$ inflow and 6.75 $\mathrm{cm}$ outflow) into the subarachnoid space as described above and routinely performed in our laboratory (Liu et al., 2011a). Immediately after cannulation, the intrathecal space was perfused ( $5 \mu$ l per min) using a push-pull method with Krebs-Ringer buffer prewarmed to $37^{\circ} \mathrm{C}$. To minimize EM2 degradation, the outflow tubing and collection tubes were kept on ice. The intrathecal space was equilibrated via 10 min perfusion with Krebs-Ringer buffer before collecting perfusate samples. Thereafter, two $10 \mathrm{~min}$ samples (one before and one after intrathecal treatment) were collected from each animal to quantify dynorphin release. Intrathecal treatment was applied immediately following the first sample collection; a 10 min waiting period was imposed before the second sample collection.

The content of dynorphin in intrathecal perfusate was quantified using a competitive enzyme immunoassay (Peninsula Laboratories) as we previously described (Liu et al., 2011a, 2013). The anti-dynorphin antibody used for immunoassay of perfusate is highly selective for dynorphin: it does not recognize dynorphin 1-13, dynorphin 1-8, $\alpha$-neoendorphin, $\beta$-endorphin, dynorphin $\mathrm{B}$, or leu-enkephalin (Gintzler et al., 2008). Biotinylated-dynorphin (6 pg/well; Peninsula Laboratories) was used as tracer. Plates were counted by an Envision 2102 Multilabel Plate Reader (PerkinElmer). A standard curve (2-32 pg/assay well) in which the value of absorbance was plotted against the log concentration of unlabeled dynorphin in the reaction well was generated in each assay. Values of experimental samples were calculated from the standard curve using the linear regression function of Prism (v5; GraphPad Software).

Intrathecal administration of drugs and behavioral testing. EM2 was dissolved in $5 \mu \mathrm{l}$ of $3 \%$ dimethyl sulfoxide; 1,3-bis(4-hydroxyphenyl)-4methyl-5-[4-(2-piperidinylethoxy)phenol]-1H-pyrazole dihydrochloride (MPP; an ER $\alpha$-selective antagonist) and 6-amino- $N$-cyclohexyl-N, 3-dimethylthiazolo[3,2-a]benzimidazole-2-carboxamide hydrochloride (LY341495; an mGluR $_{2 / 3}$ antagonist) were dissolved in $3 \mu$ l of dimethyl sulfoxide; riluzole (a glutamate release inhibitor), nor-binaltorphimine (norBNI; a KOR antagonist), and anti-dynorphin antibody were dissolved or diluted in $5 \mu \mathrm{l}$ of water. All drugs were obtained from Tocris 
Bioscience, except norBNI and anti-dynorphin antibody, which were obtained from the National Institute on Drug Abuse and Bachem, respectively. Drugs were applied to the spinal cord subarachnoid space over a $60 \mathrm{~s}$ period via a permanent indwelling intrathecal cannula. Complete delivery was ensured by flushing the cannula with an additional $10 \mu \mathrm{l}$ of saline. Doses of ER and mGluR antagonists were the same as those we previously used (Liu et al., 2011b), calculated to be $1 \%$ of those reported for systemic administration.

Assessment of tail-flick latency. Nociceptive response thresholds were assessed using radiant heat as the nociceptive stimuli. Tail-flick latency (TFL) was quantified by using a Tail Flick Analgesia Meter (IITC Life Science). Intensity of the radiant heat was adjusted such that baseline values were in the range of 3.0 to $4.5 \mathrm{~s}$. A cutoff of $10 \mathrm{~s}$ latency prevented any untoward consequences to the tail. Data were expressed as the absolute TFL.

Membrane preparation, immunoprecipitation, and Western blot analysis. Spinal cord membranes were prepared and solubilized as routinely performed by this laboratory (Chakrabarti et al., 2010). Briefly, animals were killed by decapitation; spinal tissue was homogenized in cold $20 \mathrm{~mm}$ HEPES, pH 7.4, containing 10\% sucrose, 5 mM EDTA, 1 mm EGTA, 2 mM dithiothreitol, and multiple protease inhibitors [ $1 \mathrm{~mm}$ benzamidine, 0.2 $\mathrm{g} / \mathrm{L}$ bacitracin, $2 \mathrm{mg} / \mathrm{L}$ aprotinin, $3.2 \mathrm{mg} / \mathrm{L}$ each of leupeptin and trypsin inhibitor from soybean; $20 \mathrm{mg} / \mathrm{L}$ each of N-tosyl-L-phenylalanine chloromethyl ketone, $\mathrm{N}^{\mathrm{a}}$-p-tosyl-L-lysin chloromethyl ketone, and phenylmethylsulfonyl fluoride and cOmplete mixture protease inhibitor tablet $/ 50 \mathrm{ml}$ (Roche Molecular Biochemicals)]. Supernatants from a lowspeed spin $\left(1000 \times g\right.$ for $\left.10 \mathrm{~min}, 4^{\circ} \mathrm{C}\right)$ were centrifuged at a higher speed $\left(30,000 \times g\right.$ for $\left.40 \mathrm{~min}, 4^{\circ} \mathrm{C}\right)$ to obtain crude membrane pellets. Membranes were solubilized in the above buffer without sucrose and dithiothreitol but now containing $150 \mathrm{~mm} \mathrm{NaCl}, 1 \%$ Nonidet P-40, $0.5 \%$ $\mathrm{Na}$-deoxycholate, $0.1 \% \mathrm{Na}$-dodecyl sulfate, and $10 \%$ glycerol, agitated for $60 \mathrm{~min}$ at $4^{\circ} \mathrm{C}$ and centrifuged $\left(16,000 \times g\right.$ for $40 \mathrm{~min}$ at $\left.4^{\circ} \mathrm{C}\right)$. Immunoprecipitations (IPs) were obtained (overnight incubation at $4^{\circ} \mathrm{C}$ ) from equivalent solubilized membrane protein (measured by Bradford assay; Bradford, 1976) using specific antibodies and protein A or G agarose beads. IP samples were washed, eluted with heat in SDS sample buffer, separated by SDS-PAGE, transferred onto nitrocellulose membrane, and Western blotted.

Coimmunoprecipitates (co-IPs) to be compared were always obtained and processed in parallel. Western quantification of the coimmunoprecipitated protein was always normalized against the protein targeted for direct IP, which was also quantified by Western analysis using antibodies against a different epitope. Moreover, Western blots of all immunoprecipitated proteins (those directly targeted as well as coimmunoprecipitated) used antibodies raised in a host different from that used for the generation of antibodies used for IP to avoid cross-recognition by secondary antibodies (which was confirmed in the current study). The antibody-substrate complex was visualized using Supersignal West Dura kit (Pierce). Chemiluminescence was captured via a G:Box CCD camera (Syngene) and intensities quantified using Genetools software (Syngene).

Specificity of Western blot signals [that of the directly immunoprecipitated protein as well as coimmunoprecipitated protein(s)] was validated by their absence when Western blotting using preadsorbed antibody [antigenic peptide used for generation of the antibody was diluted in 20 mM HEPES, pH 7.4, at five times excess to antibody and covalently coupled to Affi-Gel 10 Gel matrix in accordance with the manufacturer's instructions (Bio-Rad). The desired antibody was added in Tris-buffered saline (TBS) and allowed to preadsorb. Following incubation, the flow-through was collected ("preadsorbed antibody")]. This was used to probe one of two identical nitrocellulose membrane strips containing the protein of interest (the other strip was probed in parallel with an equivalent amount of primary antibody and the difference in signal intensity quantified).

Blue native PAGE/SDS-PAGE. Native sample buffer and the anionic dye Coomassie Blue G-250 were added to solubilized spinal membrane samples and electrophoresed using $3-12 \%$ blue native gels (Invitrogen). Blue native PAGE was performed as previously described (Schägger and von Jagow, 1991). The migration distances of individual bands relative to marker proteins were used to estimate masses of membrane proteins. The $\approx 360 \mathrm{kDa}$ blue band was excised. Then, proteins contained therein were eluted with $50 \mathrm{~mm}$ Tris- $\mathrm{HCl}$ containing $150 \mathrm{~mm} \mathrm{NaCl}$, and $0.1 \mathrm{~mm}$ EDTA, pH 7.5, was separated using SDS-PAGE and immunoblotted for $\mathrm{KOR}$ and $\mathrm{mGluR}_{2 / 3}$, as previously described for aromatase, $\mathrm{ER} \alpha, \mathrm{MOR}$, and $\mathrm{mGluR}_{1}$ (Liu et al., 2017).

Sequential IP. Membranes were solubilized in 20 mM HEPES buffer, $\mathrm{pH} 7.4$, containing $1 \mathrm{~mm}$ EDTA, protease inhibitors as above, and $2 \%$ mild detergent digitonin, incubated on ice (60 $\mathrm{min})$, and centrifuged $\left(15,000 \times g, 20 \mathrm{~min}, 4^{\circ} \mathrm{C}\right)$. Clear supernatants were used for protein determination (Bradford assay; Bradford, 1976) and sequential IP, which used antibodies against aromatase, $\mathrm{ER} \alpha, \mathrm{mGluR}_{1}, \mathrm{mGluR}_{2 / 3}$, and KOR. Samples were incubated with antibody cross-linked to protein A or G agarose beads using disuccinimidyl suberate (Thermo Fisher Scientific), washed, and gently eluted with $100 \mathrm{~mm}$ glycine, $\mathrm{pH}$ 2.5. Eluate was neutralized ( $1 \mathrm{M}$ Tris, $\mathrm{pH} 8.8$ ) and incubated with the next antibody. The final IP was eluted with $100 \mathrm{~mm}$ glycine. Native sample buffer and Coomassie Blue were added to eluted final IP, which was followed by electrophoresis using 3-12\% blue native gels and electro-transfer onto polyvinylidene difluoride membranes. Anti-MOR Western blot analysis was performed as reported (Chakrabarti et al., 2010). Since we had previously demonstrated the specificity of MOR and KOR Western blot signals in the spinal cord (Chakrabarti et al., 2010), this control was not repeated in the present study.

Immunocytochemistry. Proestrus female rats were deeply anesthetized with a mixture of ketamine $(68 \mathrm{mg} / \mathrm{kg})$, xylazine $(4.6 \mathrm{mg} / \mathrm{kg})$, and acepromazine $(0.9 \mathrm{mg} / \mathrm{kg})$ and perfused through the ascending aorta with $100 \mathrm{ml}$ of ice-cold oxygenated calcium-free Tyrode's buffer $(115 \mathrm{~mm}$ $\mathrm{NaCl}, 5 \mathrm{~mm} \mathrm{KCl}, 2 \mathrm{~mm} \mathrm{MgCl} \cdot \cdot 6 \mathrm{H}_{2} \mathrm{O}, 400 \mu \mathrm{M} \mathrm{MgSO}_{4} \cdot \mathrm{H}_{2} \mathrm{O}, 3 \mathrm{~mm}$ glucose, and $25 \mathrm{~mm} \mathrm{NaHCO}_{3}$, pH 7.2) followed by $500 \mathrm{ml}$ of freshly prepared buffered formaldehyde ( $4 \% \mathrm{w} / \mathrm{v}$ formaldehyde, $14 \% \mathrm{v} / \mathrm{v}$ saturated aqueous picric acid, $75 \mathrm{~mm} \mathrm{KH_{2 }} \mathrm{PO}_{4}$, and $85 \mathrm{~mm} \mathrm{Na}_{2} \mathrm{HPO}_{4} \cdot 7 \mathrm{H}_{2} \mathrm{O}$, pH 6.9). After fixation, the entire vertebral column, including the pelvis, was harvested, placed in cryoprotectant solution (15 mm sucrose, $30 \mathrm{~mm}$ $\mathrm{K}_{2} \mathrm{HPO}_{4}$, and $70 \mathrm{~mm} \mathrm{Na}_{2} \mathrm{HPO}_{4} \cdot \mathrm{H}_{2} \mathrm{O}, \mathrm{pH}$ 7.2), and shipped via overnight air courier service to Minnesota on refrigerant gel packs.

Upon arrival, spinal levels were identified, tissue was quickly frozen, and serial sections were cut to a nominal thickness of $5 \mu \mathrm{m}$ on a cryostat (Bright Instruments). Sections were then thawed onto Probe-On Plus microscope slides (Thermo Fisher Scientific) and stored at $-20^{\circ} \mathrm{C}$ until used. Heat-induced antigen retrieval was used to improve staining. Sections were rinsed in distilled water and immersed in citrate buffer $(10 \mathrm{mM}$ trisodium citrate adjusted to $\mathrm{pH}$ 6.0) containing 0.05\% Tween 20 and autoclaved at $101^{\circ} \mathrm{C}$ for $30 \mathrm{~min}$. The sections were allowed to cool to room temperature, rinsed in TBS $(135 \mathrm{~mm} \mathrm{NaCl}$ and $25 \mathrm{~mm}$ Tris- $\mathrm{HCl}$, $\mathrm{pH}$ 7.4), then incubated in permeabilization solution (TBS containing $0.2 \%$ Triton X-100 and $0.2 \%$ Tween 20 ) for $1 \mathrm{~h}$ at room temperature. The sections were then incubated with either guinea pig anti-dynorphin or guinea pig anti-MOR1 (staining for which was not observed in MOR knock-out mice), either mouse anti- $\mathrm{mGluR}_{1}$ (generated against rat $\mathrm{mGluR}_{1}$ amino acids 1042-1160, highly divergent from the corresponding sequence of $\mathrm{mGluR}_{5}$ ) or a mixture of mouse antibody against the vesicular glutamate transporter (VGLUT) 1 (VGLUT1) and VGLUT2, and either rabbit anti-mGluR $\mathrm{R}_{2 / 3}$ or rabbit anti-ER $\alpha$ [the staining specificity of which has previously been validated by preadsorption (Zeps et al., 1998) and by confirming immunohistochemical results with a second anti-ER $\alpha$ antibody generated against a different epitope (Shim et al., 1999)]. Antibodies were diluted in blocking buffer (TBS containing $0.1 \%$ Tween 20 and $0.2 \%$ casein). The sections were washed twice with TBS and once with permeabilization solution over $1 \mathrm{~h}$ at room temperature. The sections were incubated for $2 \mathrm{~h}$ at room temperature in blocking buffer containing a mixture of $3 \mu \mathrm{g} / \mathrm{ml}$ each of donkey anti-rabbit IgG conjugated to $\mathrm{Cy} 3$, donkey anti-guinea pig IgG conjugated to $\mathrm{Cy} 2$, and donkey anti-mouse conjugated to Cy5 (Jackson ImmunoResearch Laboratories). The sections were washed in three changes of TBS, rinsed in distilled $\mathrm{H}_{2} \mathrm{O}$, dehydrated in increasing concentrations of ethanol (50$100 \%$ ), and cleared in xylene. The slides were mounted with coverslips using DPX Mountant (Fluka). 


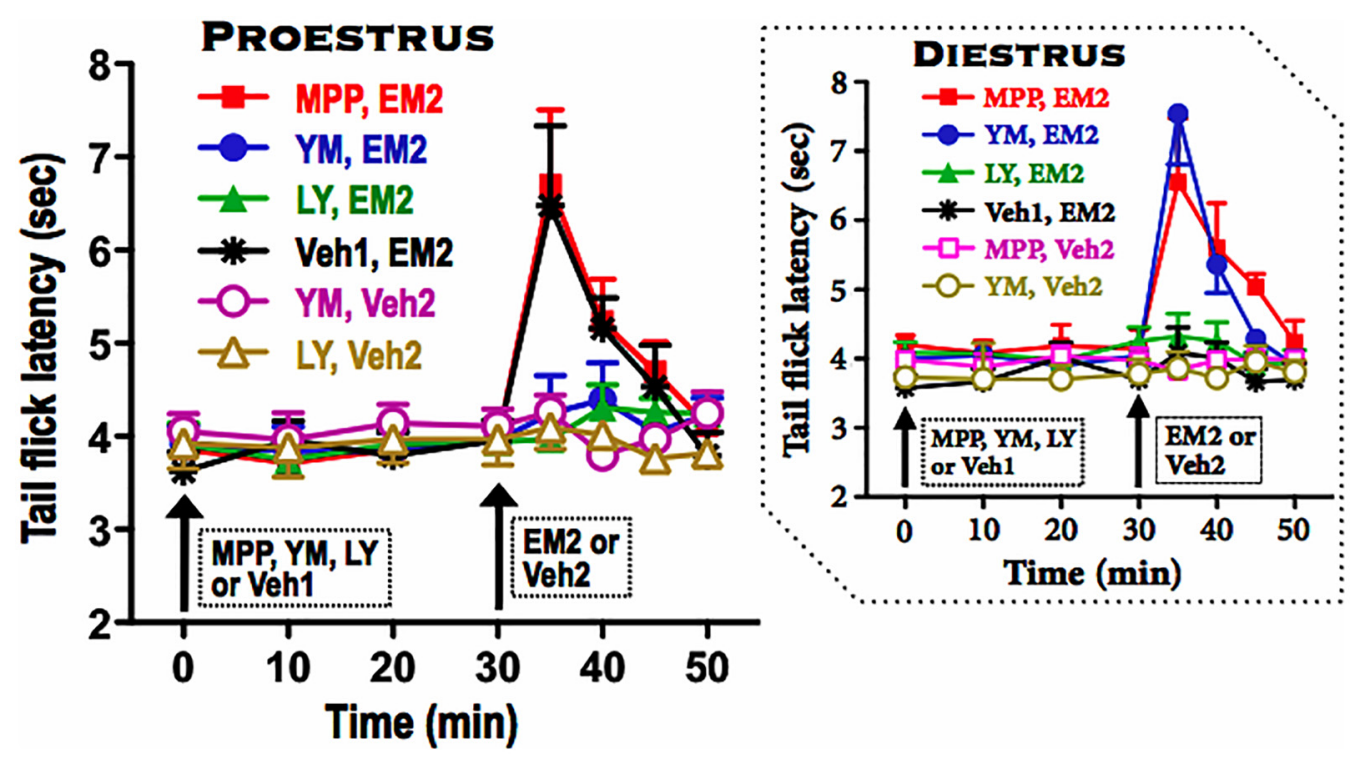

Figure 1. Blockade of spinal $\mathrm{mGluR}_{1}$ or $\mathrm{mGluR}_{2 / 3}$, but not $\mathrm{mER} \alpha$, inhibits spinal $E M 2$ antinociception during proestrus. Antinociception was quantified using tail-flick test at the indicated times. Intrathecal EM2 was administered 30 min after either blockade of spinal mGluR [ (via intrathecal $25 \mathrm{nmol}$ YM298198 (YM)], mGluR [ [via intrathecal $25 \mathrm{nmol}$ LY341495 (LY)], or ER $\alpha$ (via intrathecal $10 \mathrm{nmol}$ MPP) or DMSO vehicle control (Veh1). Inset shows the corresponding data from diestrus rats (Liu et al., 2017). Contribution of spinal mGluRs and ER $\alpha$ to intrathecal EM2 antinociception is specific to stage of estrous cycle. In proestrus, activity of both $\mathrm{mGluR}_{1}$ and $\mathrm{mGluR}_{2 / 3}$ is essential for spinal EM2 antinociception, while ER $\alpha$ does not contribute. In contrast, in diestrus, the activity of both $m G l u R_{1}$ and $m E R \alpha$ are required to suppress spinal EM2 analgesic responsiveness, whereas $m_{G l u R} / 3$ does not participate. $n=4-7$. Veh2 was $3 \%$ DMSO. Data are expressed as mean \pm SEM.

Microscopy. Images of labeling were collected using an Olympus Fluoview 1000 confocal microscope equipped with excitation at $488 \mathrm{~nm}$ (Cy2), $543 \mathrm{~nm}$ (Cy3), and $635 \mathrm{~nm}$ (Cy5). Images were collected with 40X 1.3 numerical aperture or $60 \times 1.4$ numerical aperture objectives and pixel dimensions of $\leq 0.32 \mu \mathrm{m}$; all images were made using sequential scanning to avoid bleed-through. Adobe PhotoShop was used to apply pseudocolor to images and to adjust brightness and contrast (Liu et al., 2013).

Antibodies. The following antibodies were used: IP: anti-aromatase (sc-14245; $3 \mu \mathrm{g}$ per $800 \mu \mathrm{g}$ of total protein), anti-ER $\alpha$ (sc-71064; $3 \mu \mathrm{g}$ per $800 \mu \mathrm{g}$ of total protein; Kumar et al., 2015), anti-KOR (raised against amino acids 1-70; sc-7494; $2 \mu \mathrm{g}$ per $800 \mu \mathrm{g}$ of total protein; Chakrabarti

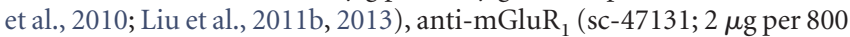
$\mu \mathrm{g}$ of total protein), all purchased from Santa Cruz Biotechnology, and anti-mGluR $2 / 3$ (US Biologicals, M3884-76G; $3 \mu \mathrm{g}$ per $800 \mu \mathrm{g}$ of total

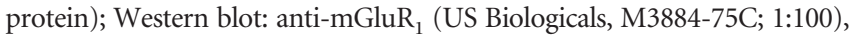
anti-MOR (generous gift from Dr. Thomas Cote; 1:1000; Chalecka-

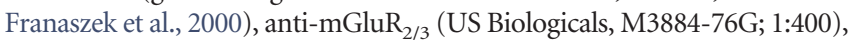
anti-KOR (Pierce, generated against amino acids 262-275; 1:1000; Chakrabarti et al., 2010; Liu et al., 2011b); immunocytochemistry (ICC): anti-ER $\alpha$ (SCB, sc-542; 1:1000; Liu et al., 2011b), anti-MOR (raised in guinea pig against amino acids 384-398 of MOR1; 1:1000; Arvidsson et al., 1995b), anti-mGluR 1 (BD Biosciences, 610964; 1:1000; this antibody was generated against a region of rat $\mathrm{mGluR}_{1}$ that is highly divergent from that of $\mathrm{mGluR}_{5}$; thus, it is unlikely to be cross-reactive with $\mathrm{mGluR}_{5}$, as has been previously suggested for earlier reports of $\mathrm{mGluR}_{1}$ in laminae I-II; Alvarez et al., 2000); anti- $\mathrm{mGluR}_{2 / 3}$ (US Biologicals, M3884-76G); anti-preprodynorphin 235-248 (generated against preprodynorphin 235-248, a cryptic portion of the dynorphin precursor that serves as a marker peptide for dynorphin; Arvidsson et al., 1995a; Liu et al., 2013), and anti-VGLUT (a mixture of antibodies against VGLUT1 and VGLUT2; Millipore Bioscience Research Reagents).

Statistical analyses. One-way ANOVA was used to analyze withingroup treatment effects while two-way ANOVA was used to compare treatment by time effects on TFL between/among groups. Unpaired Student's $t$ test was used to analyze differences in Western blot signals of coimmunoprecipitated proteins as well as spinal dynorphin release. $p<$ 0.05 was considered significant. Statistical comparisons were made using Prism 5 software.

\section{Results}

Altered functional interactions among spinal $m E R \alpha$, $\mathrm{mGluR}_{1}$, and $\mathrm{mGluR}_{2 / 3}$ underlie the transition from spinal EM2 analgesically nonresponsive to responsive states

During diestrus, $\mathrm{mER} \alpha$ and $\mathrm{mGluR}_{1}$ activity restricts spinal EM2 analgesia (Liu et al., 2017). Using TFL, we investigated whether the emergence of spinal EM2 antinociception during proestrus results simply from the negation of this suppressive modulation or the development of alternative facilitative signaling (Fig. 1).

Although spinal $\mathrm{mER} \alpha$ blockade (via intrathecal MPP, 10 nmol, 30 min before EM2) unmasked EM2's antinociceptive effect during diestrus (Liu et al., 2017), the same treatment during proestrus did not alter intrathecal EM2 $(45 \mathrm{nmol})$ analgesia $\left[F_{(1,33)}=0.112, p=0.744\right.$, MPP-pretreated vs vehicle (DMSO)pretreated group; $n=6-7$; Fig. 1]. Paradoxically, blockade of

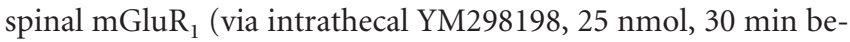
fore EM2; which unmasks intrathecal EM2 analgesia during diestrus) actually eliminated the spinal EM2 antinociception during proestrus $\left[F_{(1,36)}=4.923, p=0.046\right.$, YM298198pretreated vs vehicle (water)-pretreated group; $n=7$ ]. Additionally, blockade of $\mathrm{mGluR}_{2 / 3}$ (via intrathecal LY341495, $25 \mathrm{nmol}$, 30 min before EM2, which did not alter the minimal antinociception produced by intrathecal EM2 during diestrus) also eliminated proestrus-associated spinal EM2 antinociception $\left[F_{(1,33)}=\right.$ 5.012, $p=0.047$, LY341495-pretreated vs vehicle (DMSO)pretreated group; $n=6-7]$. Neither intrathecal YM298198 nor LY341495, in the absence of EM2 but presence of EM2 vehicle, altered TFL $\left(F_{(4,12)}=1.17, p=0.372\right.$ for YM298198 and $F_{(4,12)}=$ $1.18, p=0.368$ for LY341495; $n=4)$. We did not test the effect of intrathecal MPP in the presence of EM2 vehicle since intrathecal MPP did not alter intrathecal EM2 antinociception in proestrus. This indicates that the transition from being nonresponsive to spinal EM2 (during diestrus) to being analgesically responsive (during proestrus) resulted from the negation of suppressive 

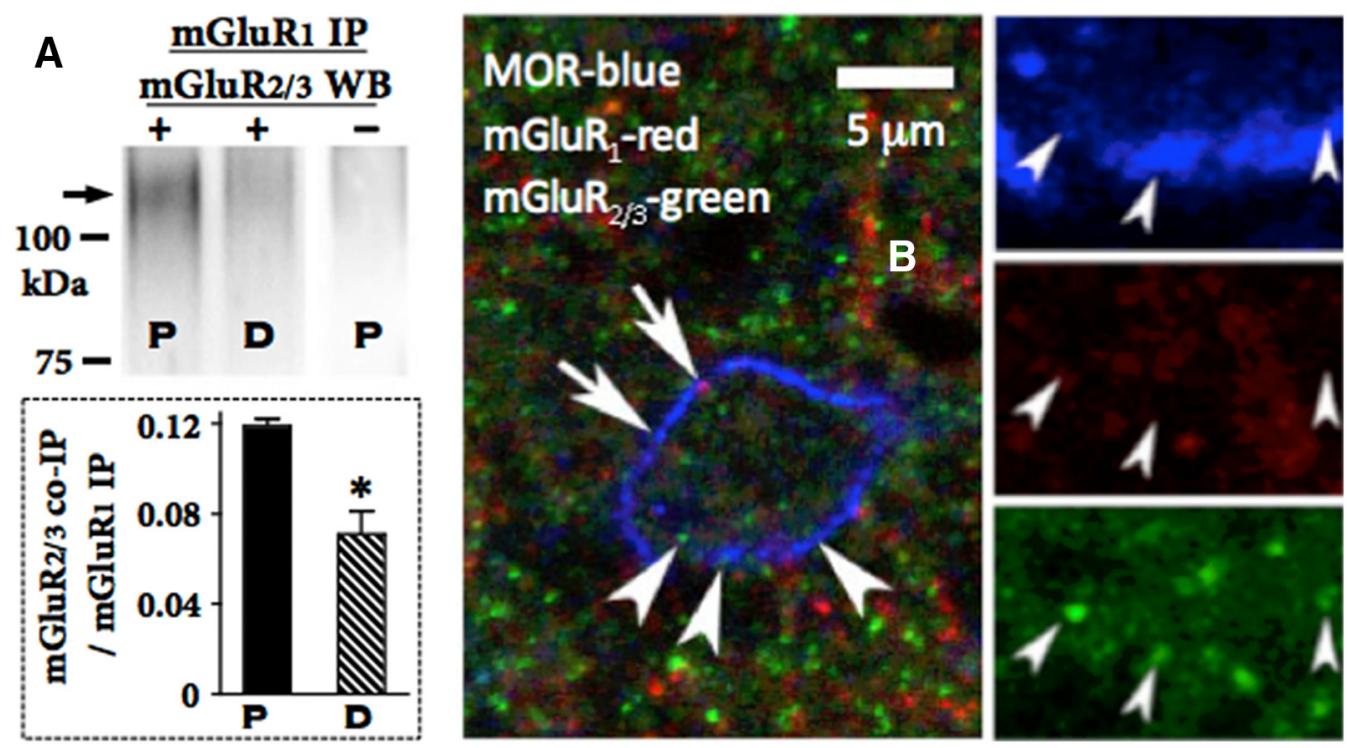

Figure 2. Co-IP and coexpression of $\mathrm{mGluR}_{1}$ and $\mathrm{mGluR}_{2 / 3}$ in proestrus versus diestrus. $A$, solubilized spinal cord membrane fractions were immunoprecipitated using an antibody selective for $m G l u R_{1}$. Immunoprecipitates were Western blotted using an antibody selective for $m_{G l u R_{2 / 3}}(+)$. The co-IP of $m G l u R_{2 / 3}$ with $m G l u R_{1}$ is markedly elevated in proestrus (P) versus diestrus (D). Specificity of anti-mGluR $R_{2 / 3}$ antibody was confirmed by the absence of the Western blot signal when the sample was incubated with preadsorbed ( - ) anti-mGluR $R_{2 / 3}$ antibody. Bar graph in $A$ shows quantification of signal intensity after normalizing with the corresponding mGluR $_{1}$ that was directly immunoprecipitated. Specificity of the anti-mGluR ${ }_{1}$ antibodies was demonstrated by Liu et al. (2017). ${ }^{*} p<0.05$, D versus $P, n=6$ for each group. $B$, left, Coexpression of $\mathrm{mGluR}_{1}$ (red; arrows) and $\mathrm{mGluR}_{2 / 3}$ (green; arrowheads) in a MOR-expressing neuron. Right, $2 \times$ higher-magnification images of bottom-middle part of that neuron, showing expression in that region. MOR, Blue; $\mathrm{mGluR}_{1}$, red; $\mathrm{mGluR}_{2 / 3}$, green. These data provide a cellular basis for the cooperative modulation of intrathecal EM2 antinociception by $m G l u R_{1}$ and $m$ GluR $_{2 / 3}$. Data in bar graph are expressed as mean $+\mathrm{SEM}$.

$\mathrm{mER} \alpha-\mathrm{mGluR}_{1}$ modulation as well as the emergence of $\mathrm{mGluR}_{1}$ $\mathrm{mGluR}_{2 / 3}$ facilitative modulation.

Association of $\mathrm{mGluR}_{1}$ with $\mathrm{mGluR}_{2 / 3}$ is augmented in spinal cord of proestrus versus diestrus rats

Dependence of spinal EM2 antinociception on the concomitant activation of $\mathrm{mGluR}_{1}$ and $\mathrm{mGluR}_{2 / 3}$ in proestrus (but not diestrus) suggested convergence of their signaling pathways contingent on stage of estrous cycle. We investigated whether the intersection of signaling pathways occurred at the level of the receptors themselves, which would be reflected by their increased co-IP during proestrus versus diestrus. Accordingly, we quantified via Western blot analysis the content of $\mathrm{mGluR}_{2 / 3}$ in IP obtained from spinal membranes using anti- $\mathrm{mGluR}_{1}$ antibodies. $\mathrm{mGluR}_{1} \mathrm{IP}$ obtained from proestrus rats contained small but demonstrable quantities of $\mathrm{mGluR}_{2 / 3}$. In contrast, $\mathrm{mGluR}_{2 / 3}$ was barely detectable in $\mathrm{mGluR}_{1}$ IP obtained in diestrus rats $\left(t_{(5)}=6.09, p=0.002\right.$, unpaired $t$ test for proestrus vs diestrus; Fig. $2 A$ ). These results reveal not only the physical association of $\mathrm{mGluR}_{1}$ and $\mathrm{mGluR}_{2 / 3}$, but also the plasticity of this association over the estrus cycle.

\section{MOR-expressing spinal neurons coexpress $\mathrm{mGluR}_{1}$ and mGluR $_{2 / 3}$} Co-IP of $\mathrm{mGluR}_{1}$ and $\mathrm{mGluR}_{2 / 3}$ suggests but does not unequivocally establish their coexpression, which is critical for physiological relevance. Neuronal coexpression of MOR, $\mathrm{mGluR}_{1}$, and $\mathrm{mGluR}_{2 / 3}$ in the superficial dorsal horn of $\mathrm{S} 1$ spinal cord in a proestrus rat is illustrated in Figure $2 B$. $\mathrm{mGluR}_{1}$ immunoreactivity (arrows) and $\mathrm{mGluR}_{2 / 3}$ immunoreactivity (arrowheads) are found in or near the plasma membrane of a MOR-immunoreactive neuron (insets: a $2 \times$ higher magnification of the bottom half of the neuron; arrowheads correspond to the arrowheads in the main figure). This coexpression of $\mathrm{mGluR}_{1}$ and $\mathrm{mGluR}_{2 / 3}$ in MOR-expressing neurons not only provides a cellular context for their co-IP, but also satisfies the requirement for their concomitant activation for intrathecal EM2 antinociception to be manifest during proestrus. Interestingly, although the intracellular distribution of $\mathrm{mGluR}_{1}$ and $\mathrm{mGluR}_{2 / 3}$ within a MOR-immunoreactive cell overlapped, the majority did not. This suggests that interactions between $\mathrm{mGluR}_{1}$ and $\mathrm{mGluR}_{2 / 3}$ are not only dynamic and temporally regulated, but that the coimmunoprecipitated $\mathrm{mGluR}_{1}$ and $\mathrm{mGluR}_{2 / 3}$ represent a minority of their respective populations.

Spinal dynorphin release depends on stage of estrous cycle We previously reported that spinal EM2 analgesia in proestrus requires spinal dynorphin as well as KOR (in addition to MOR) signaling (Liu and Gintzler, 2013). Based on this, we hypothesized that the ability of spinal EM2 to produce antinociception is influenced by variability in spinal dynorphin release, suppressed in diestrus but enabled in proestrus.

To test this hypothesis, we quantified spinal dynorphin release into spinal perfusate during diestrus and proestrus (Fig. 3). During diestrus, spinal dynorphin release was $1.70 \pm 0.20 \mathrm{fmol} / 10$ $\min (n=21)$, whereas during proestrus dynorphin release was significantly higher $(3.07 \pm 0.56 \mathrm{fmol} / 10 \mathrm{~min} ; n=18)$. The nearly twofold increment in spinal dynorphin release during proestrus versus diestrus $\left(t_{(37)}=2.36, p=0.024\right.$, unpaired $t$ test $)$ is consistent with our earlier pharmacological demonstration that spinal dynorphin/KOR activity significantly affects intrathecal EM2 analgesic responsiveness (Liu and Gintzler, 2013).

Spinal dynorphin/KOR activity is required for $\mathrm{mER} \alpha$ or $\mathrm{mGluR}_{1}$ blockade to unmask intrathecal EM2 analgesic responsiveness during diestrus

During proestrus, spinal EM2 antinociception depends on spinal dynorphin/KOR signaling (Liu et al., 2013). This, in combination with the current demonstration that basal dynorphin release is higher in proestrus than diestrus, prompted us to investigate whether spinal dynorphin release and/or KOR activation are also essential for the spinal EM2 antinociception unmasked during 


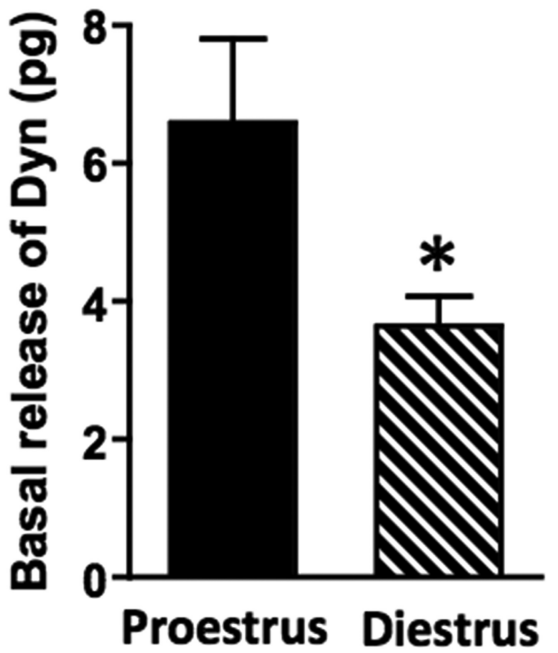

Figure 3. Basal spinal dynorphin release depends on stage of estrous cycle. Magnitude of basal spinal dynorphin (Dyn) release is greater in proestrus versus diestrus $\left({ }^{*} p<0.05 ; n=18\right.$ and 21, respectively). This suggests a positive correlation between the magnitude of basal spinal Dyn release and spinal EM2 antinociception. Data are expressed as mean + SEM.

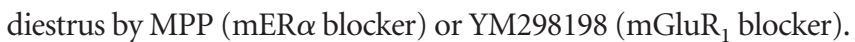
Accordingly, we investigated the effects of intrathecal antidynorphin antibodies (DynAb; $300 \mathrm{ng}, 30 \mathrm{~min}$ before EM2) or intrathecal norBNI (KOR-selective antagonist; $26 \mathrm{nmol}, 18 \mathrm{~h}$ before EM2) on the ability of MPP or YM298198 to unmask spinal EM2 antinociception during diestrus. Strikingly, both intrathecal treatments eliminated the intrathecal EM2 antinociception that emerged after blocking either spinal $m E R \alpha$ or $\mathrm{mGluR}_{1}$ (Fig. $4 A$ : $F_{(1,56)}=3.36, p=0.09$ for $\mathrm{MPP}+\mathrm{DynAb}+\mathrm{EM} 2$ vs vehicle + EM2; $F_{(1,52)}=0.39, p=0.544$ for $\mathrm{MPP}+$ norBNI+EM2 vs vehicle+EM2; Fig. $4 B: F_{(1,48)}=1.26, p=0.283$ for YM298198+ DynAb+EM2 vs vehicle+EM2; $F_{(1,60)}=0.88, p=0.362$ for $\mathrm{YM} 298198+$ norBNI+EM2 vs vehicle+EM2; $n=5-7)$. As expected, vehicle for DynAb/norBNI had no effect $\left(F_{(1,49)}=0.47\right.$, $p=0.514$ and $F_{(1,70)}=0.003, p=0.954$ for MPP and YM298198, respectively; $n=4-7$ ). Furthermore, as previously reported (Liu et al., 2013), neither intrathecal DynAb nor intrathecal norBNI altered TFL in the absence or presence of intrathecal EM2 in diestrus.

These data suggest that during diestrus, unmasking spinal EM2 antinociception by blocking spinal $m E R \alpha$ or $\mathrm{mGluR}_{1}$ results from disinhibiting spinal dynorphin release/KOR signaling. This implies that a threshold level of endogenous spinal dynorphin/KOR signaling is a prerequisite for intrathecal EM2 antinociception. This inference is supported by the ability of intrathecal EM2 to produce analgesia during diestrus when rats are pretreated (30 min before EM2) with intrathecal dynorphin (Fig. 4C; 3 nmol dynorphin: $F_{(4,12)}=3.98, p=0.03 ; 5$ nmol dynorphin: $F_{(4,12)}=3.99, p=0.03$; both comparing TFL before vs after intrathecal dynorphin+EM2, $n=5-6$ ). In contrast, $1.5 \mathrm{nmol}$ intrathecal dynorphin was insufficient to unmask spinal EM2 antinociception $\left(F_{(4,16)}=1.29, p=0.312, n=5\right)$. Intrathecal dynorphin $(5 \mathrm{nmol})$, in the absence of EM2 but the presence of its vehicle, did not alter TFL $\left(F_{(4,12)}=0.39, p=0.813, n=4\right)$.

EM2 inhibits spinal dynorphin release, which requires mER $\alpha$ and $\mathrm{mGluR}_{1}$ activity in diestrus

The ability of spinal dynorphin/KOR antagonism to eliminate the spinal EM2 analgesic responsiveness that emerges following $\mathrm{mER} \alpha$ or $\mathrm{mGluR}_{1}$ blockade could indicate that during diestrus
$\mathrm{mER} \alpha$ and $\mathrm{mGluR}_{1}$ are each able to suppress dynorphin release, thereby curtailing spinal EM2 analgesic responsiveness. To test this hypothesis, we determined the influence of blocking spinal $\mathrm{mER} \alpha$ or $\mathrm{mGluR}_{1}$ on spinal dynorphin release while in the presence of EM2 (Fig. 5), mirroring the behavioral experiments described above.

An analgesically effective dose of intrathecal EM2 (45 nmol) significantly inhibited $(\approx 53 \%)$ spinal dynorphin release during diestrus $\left(t_{(7)}=4.53, p=0.003\right.$, paired $t$ test) as well as proestrus $\left(\approx 45 \% ; t_{(5)}=3.39, p=0.019\right.$, paired $t$ test $)$. During diestrus, in the absence of EM2, dynorphin release was not altered by blocking $\mathrm{mGluR}_{1}$ or $\operatorname{mER} \alpha\left(t_{(14)}=0.06, p=0.956\right.$, unpaired $t$ test for $\mathrm{mGluR}_{1}$ blocker; $t_{(8)}=1.19, p=0.265$, unpaired $t$ test for $\mathrm{ER} \alpha$ blocker). Nevertheless, blocking either $\mathrm{mGluR}_{1}$ or $\mathrm{mER} \alpha$ (which unveils intrathecal EM2 analgesic responsiveness during diestrus) eliminated the inhibition of dynorphin release produced by EM2, i.e., EM2 failed to inhibit spinal dynorphin release following $\mathrm{mGluR}_{1}$ or $\mathrm{mER} \alpha$ blockade $\left(t_{(7)}=2.06, p=0.078\right.$, paired $t$ test for $\mathrm{mGluR}_{1}$ blocker; $t_{(6)}=0.74, p=0.488$, paired $t$ test for $\mathrm{ER} \alpha$ blocker). These data support the above inference that in diestrus, either spinal $\mathrm{mER} \alpha$ or $\mathrm{mGluR}_{1}$ blockade restores analgesic responsiveness to intrathecal EM2 by disinhibiting (and thereby augmenting) spinal dynorphin release.

In contrast to diestrus, blockade of $\mathrm{mGluR}_{1}$ (as well as $\mathrm{mGluR}_{2 / 3}$ ) during proestrus failed to alter EM2-induced inhibition of spinal dynorphin release, i.e., EM2 persisted in inhibiting spinal dynorphin release despite $\mathrm{mGluR}_{1}$ (or $\mathrm{mGluR}_{2 / 3}$ ) blockade $\left(t_{(5)}=2.27\right.$, $p=0.036$, paired $t$ test for $\mathrm{mGluR}_{1}$ blocker; $t_{(4)}=2.31, p=0.041$ paired $t$ test for $\mathrm{mGluR}_{2 / 3}$ blocker). The effect of blocking $\mathrm{mGluR}_{2 / 3}$ during diestrus or blocking $\mathrm{mER} \alpha$ during proestrus on the EM2 inhibition of dynorphin release was not determined since these treatments did not alter spinal EM2 antinociception (Liu et al., 2017).

\section{Plasticity of spinal $\mathrm{mGluR}_{1}$ functionality results from its differential activation by $\operatorname{mER} \alpha$ and glutamate}

We hypothesized that the antithetical modulation by $\mathrm{mGluR}_{1}$ of spinal EM2 antinociception (reflected by the opposite effects of $\mathrm{mGluR}_{1}$ antagonism) in diestrus versus proestrus resulted from switching the endogenous activator of $\mathrm{mGluR}_{1}$ from $\mathrm{mER} \alpha$ during diestrus [as has been observed in cultured hippocampal neurons (Boulware et al., 2005)] to glutamate during proestrus. In other words, we postulated that the switch from suppressive to facilitative modulation of spinal EM2 antinociception resulted from biased agonism at spinal $\mathrm{mGluR}_{1}$ by its two endogenous agonists: $\operatorname{mER} \alpha$ and glutamate.

To test this hypothesis, we determined whether blockade of spinal glutamate release would blunt intrathecal EM2 antinociception during proestrus, as was observed following spinal $\mathrm{mGluR}_{1}$ blockade. Figure 6 illustrates that during proestrus, intrathecal riluzole [a glutamate release inhibitor (Mao et al., 2002; Sung et al., 2003); 43 nmol, 1 h before EM2] eliminated intrathecal EM2 antinociception $\left(F_{(1,40)}=8.16, p=0.017, n=5-7\right.$, for Rilu+EM2 vs Veh1+EM2; $F_{(4,16)}=0.98, p=0.446, n=5$, for TFL in the absence vs presence of intrathecal riluzole+EM2). Intrathecal application of riluzole, in the absence of EM2, but presence of its vehicle, did not alter TFL $\left(F_{(4,12)}=1.25, p=0.344\right.$ for riluzole; $n=4)$. As expected, during diestrus, intrathecal riluzole had no effect on spinal EM2 nonresponsiveness $(n=4$; data not shown). Collectively, these data strongly suggest that signaling via endogenous spinal glutamate is a prerequisite for the spinal EM2 antinociception that emerges during proestrus, 

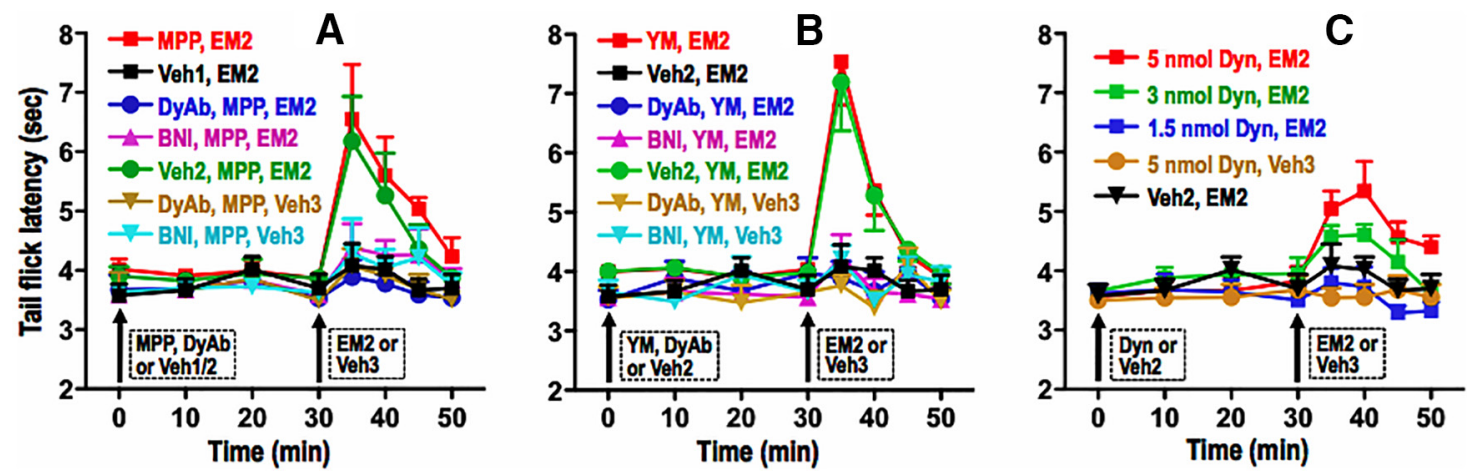

Figure 4. Activity of endogenous spinal dynorphin/KOR is a prerequisite for the spinal $E M 2$ analgesia unveiled by blocking $m E R \alpha$ or $m G l u R_{1}$ in diestrus. $A-C$, Analgesic responsiveness to intrathecal EM2 (45 nmol) was determined in diestrus following intrathecal pretreatment with either MPP (ER $\alpha$ blocker; $\boldsymbol{A}$ ), YM298198 (mGluR, blocker; $\boldsymbol{B}$, YM), or dynorphin (C, Dyn). MPP (10 $\mathrm{nmol}$ ) or YM was administered alone or in combination with anti-dynorphin antibody (DyAb, $300 \mathrm{ng}$ ) or norBNI (BNI, $26 \mathrm{nmol}$ ). MPP, YM, or DyAb was administered 30 min preceding intrathecal EM2. BNI was administered $18 \mathrm{~h}$ before intrathecal EM2. TFL was determined at the indicated times. Either intrathecal DyAb or norBNI abolished the spinal EM2 antinociception unveiled by blocking either spinal $m E R \alpha$ or GluR $_{1}$. In contrast, intrathecal Dyn unmasked intrathecal EM2 antinociception during diestrus. Pretreatment with the vehicle (water) for DyAb/BNI did not alter the ability of $m E R \alpha$ or $\mathrm{MGluR}_{1}$ antagonists to unmask intrathecal EM2 antinociception. Furthermore, neither of the indicated treatments, in the absence of intrathecal EM2, but in the presence of its vehicle ( $3 \% \mathrm{DMSO}$ ), altered TFL. $n=4-7$. Since BNI was added $18 \mathrm{~h}$ before intrathecal EM2, its indicated TFL at zero time represents that obtained $17.5 \mathrm{~h}$ after the spinal application of BNI. Veh1, DMSO (vehicle for MPP); Veh2, water (vehicle for DyAb/BNI/YM/Dyn); Veh3, 3\% DMSO (vehicle for EM2). These data indicate that suppression of endogenous spinal dynorphin/KOR signaling is causally associated with the absence of spinal EM2 analgesic responsiveness during diestrus. Data are expressed as mean \pm SEM.

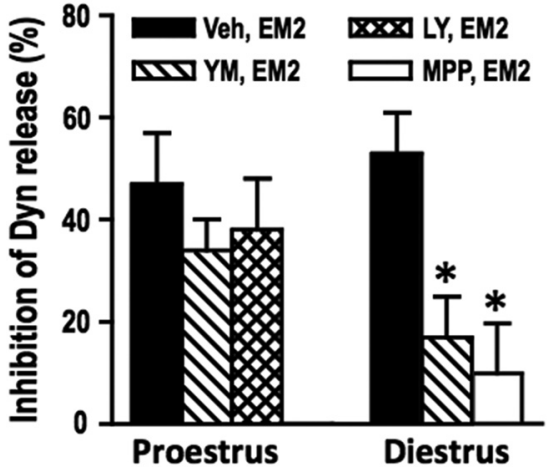

Figure 5. Activity of $m E R \alpha$ and $m G l u R_{1}$ is necessary for $E M 2$ inhibition of spinal dynorphin (Dyn) release in diestrus but not proestrus. Intrathecal EM2 ( $45 \mathrm{nmol}$ ) inhibits spinal Dyn release similarly in proestrus and diestrus, but regulation of this modulation by spinal $\mathrm{mER} \alpha$ or $\mathrm{mGluRs}$

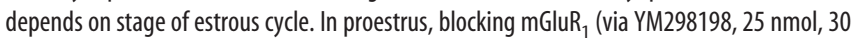
$\mathrm{min}$ ), $\mathrm{mGluR}_{2 / 3}$ (via LY341495, $25 \mathrm{nmol}, 30 \mathrm{~min}$ ), or $\mathrm{mER} \alpha$ (via MPP, $10 \mathrm{nmol}, 30 \mathrm{~min}$ ) fails to alter the EM2 inhibition of spinal Dyn release. In contrast, YM298198 and MPP profoundly attenuate EM2 inhibition of Dyn release during diestrus $(n=6-8)$. The effect on EM2 inhibition of Dyn release of blocking $\mathrm{mGluR}_{2 / 3}$ during diestrus and $\mathrm{mER} \alpha$ during proestrus was not determined since these treatments did not alter spinal EM2 antinociception. Although either YM298198 or MPP attenuates EM2 inhibition of Dyn release, these blockers failed to increase Dyn release in the absence of EM2 (but in the presence of its vehicle; data not shown). The ability of $\mathrm{mGluR}_{1}$ or ER $\alpha$ blockade to reduce EM2 inhibition of Dyn release during diestrus suggests that spinal Dyn tone is a critical determinant of spinal EM2 analgesic responsiveness. ${ }^{*} p<0.05$ for YM/MP + EM2 versus EM2 in diestrus. YM, YM298198; LY, LY341495; MP, MPP; Veh, vehicle (DMSO). Data are expressed as mean + SEM.

which implies that deficiency of spinal glutamate signaling likely underlies the lack of EM2 antinociception during diestrus.

In the spinal cord dorsal horn, spinal dynorphinergic neurons coexpressing $\mathrm{mER} \alpha$ and $\mathrm{mGluR}_{1}$ are apposed by

glutamatergic terminals

The distribution of dynorphin, $\mathrm{mER} \alpha, \mathrm{mGluR}_{1}$, and glutamate has been reported in the spinal dorsal horn (Cruz and Basbaum, 1985; Sweetnam et al., 1986; Miller and Seybold, 1989; Arvidsson et al., 1995a; Williams and Papka, 1996; Yung, 1998; Tang and Sim, 1999; Alvarez et al., 2000), as have the anatomical interrelationships among some of them (Gintzler et al., 2008; Liu et al.,

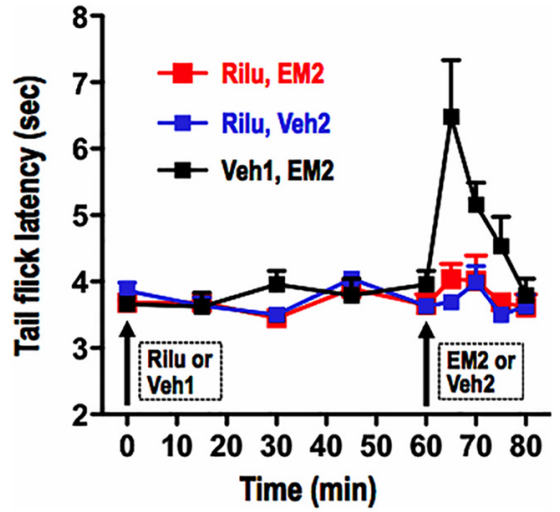

Figure 6. Glutamate is required for the manifestation of spinal EM2 analgesia during proestrus. Analgesic responsiveness to intrathecal EM2 ( $45 \mathrm{nmol}$ ) was determined using TFL following intrathecal pretreatment with riluzole (Rilu; glutamate release inhibitor, $43 \mathrm{nmol}, 1 \mathrm{~h}$ ) or its water vehicle (Veh1). Attenuation of spinal glutamatergic activity (via Rilu) eliminated spinal EM2 antinociception. Intrathecal Rilu, in the absence of intrathecal EM2, but in the presence of its vehicle, did not alter TFL. $n=4-6$. Veh2, 3\% DMSO. Data are expressed as mean + SEM.

2011b, 2017). However, it is still unclear whether the anatomical organization exists that would allow spinal dynorphin release to be modulated by ER $\alpha$-activated and glutamate-activated mGluR signaling, as our data suggest (and is critical to inferences pertaining to endogenous regulation of EM2 antinociception in cycling females). Accordingly, we investigated the anatomical relationships among spinal dynorphin, $\mathrm{mER} \alpha, \mathrm{mGluR}_{1}$, and glutamate. Figure 7 shows confocal images of two adjacent $5 \mu \mathrm{m}$ sections of a single spinal neuron in the L6 superficial dorsal horn. This neuron expressed a thin shell of dynorphin immunoreactivity in its cytoplasm, as we have described earlier (Liu et al., 2013). This neuron coexpresses $\mathrm{mGluR}_{1}$ and $\mathrm{ER} \alpha$ in or near the plasma membrane (arrowheads) and within the cell soma. Notably, this neuron is apposed by VGLUT-expressing (glutamatergic) terminals (arrow; Fig. 7, right). This anatomical organization provides a cellular basis for cycling between $\mathrm{ER} \alpha$-activated and glutamateactivated $\mathrm{mGluR}_{1}$ signaling over the estrous cycle. This organization would also enable modulation of spinal dynorphin release by glutamate, thereby coordinating glutamate activation of mGluR $_{1}$ 

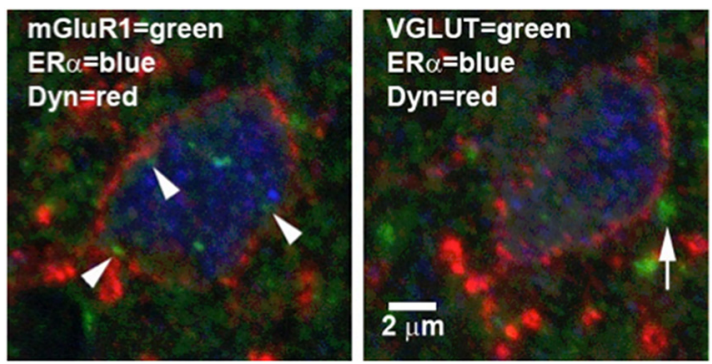

Figure 7. A single spinal dynorphinergic neuron coexpresses $E R \alpha$ and $m G l u R_{1}$ and is apposed by glutamatergic terminals. The two images are from adjacent $5 \mu \mathrm{m}$ sections through the same neuron. Left, $\mathrm{mGluR}_{1}$ (green; arrowheads), ER $\alpha$ (blue), and dynorphin (Dyn; red) are coexpressed in or near the plasma membrane in a single neuron in the spinal superficial dorsal horn of segment L6 during proestrus. Right, Glutamatergic terminals (green; arrow, stained for VGLUTs) appose the neuron expressing ER $\alpha$ and Dyn.

with dynorphin release, both of which are prerequisites for spinal EM2 antinociception during proestrus.

$\mathrm{mGluR}_{2 / 3}$ and KOR oligomerize with MOR, $\mathrm{mGluR}_{1}, \mathrm{ER} \alpha$, and aromatase in the spinal cord

ICC demonstration of coexpressed proteins does not establish their intraneuronal biochemical organization. We previously demonstrated that $\mathrm{MOR}, \mathrm{mER} \alpha, \mathrm{mGluR}_{1}$, and aromatase are not only coexpressed, but also exist, at least in part, as oligomers (Liu et al., 2017). Given our earlier demonstration of the coexpression of KOR with MOR and $\mathrm{ER} \alpha$ in spinal neurons (Liu et al., 2011b) and the dependence on spinal KOR activity for EM2 antinociception to be manifest (Liu and Gintzler, 2013), and given the current demonstration that $\mathrm{mGluR}_{2 / 3}$, in addition to $\mathrm{mGluR}_{1}$, is a prerequisite for spinal EM2 antinociception to be manifest during proestrus, we hypothesized that both $\mathrm{KOR}$ and $\mathrm{mGluR}_{2 / 3}$ would also be present in this spinal oligomer. To test this, spinal membranes were electrophoresed using blue native gels. The previously reported $\approx 360 \mathrm{kDa}$ band (Liu et al., 2017; Fig. 8A) was visualized with Coomassie Blue, excised, and eluted. Equal aliquots of the eluted band were subjected to reducing SDS-PAGE. Western blot analyses using antibody against either $\mathrm{mGluR}_{2 / 3}$ or KOR revealed that, in addition to the previously demonstrated aromatase, $\mathrm{ER} \alpha, \mathrm{mGluR}_{1}$, and MOR (Liu et al., 2017; Fig. 8B), the $\approx 360 \mathrm{kDa}$ band also contained mGluR $_{2 / 3}$ and KOR (Fig. $8 E$ ).

To differentiate between the presence of KOR and $\mathrm{mGluR}_{2 / 3}$ in a common oligomer versus different complexes that comigrated on native gels, we performed sequential IP as previously described (Liu et al., 2017) using antibody against aromatase, $\mathrm{ER} \alpha$, and $\mathrm{mGluR}_{1}$, but now with the addition of antibody against $\mathrm{KOR}$ and $\mathrm{mGluR}_{2 / 3}$. The final IP was electrophoresed using blue native gels and Western blotted with anti-MOR antibody. A $\approx 360 \mathrm{kDa}$ band (Fig. $8 D$ ) analogous to that previously reported (Liu et al., 2017; Fig. 8C) was obtained. This cross-validated the presence of $\mathrm{KOR}$ and $\mathrm{mGluR}_{2 / 3}$ in $\mathrm{a} \approx 360 \mathrm{kDa}$ oligomer that also contains aromatase, $\mathrm{mER} \alpha, \mathrm{mGluR}_{1}$, and MOR.

\section{Discussion}

This study investigated the physiological regulation of spinal EM2 antinociception over the rat estrous cycle. Findings reveal that fluctuating spinal dynorphin/KOR signaling and alternating endogenous activators of $\mathrm{mGluR}_{1}$ are key elements of that regulation. Specifically, we found the following: (1) $\operatorname{mER} \alpha-$ $\mathrm{mGluR}_{1}$ suppression of spinal EM2 antinociception during diestrus results from their inhibition of spinal dynorphin release and consequently diminished KOR activation (both of which are

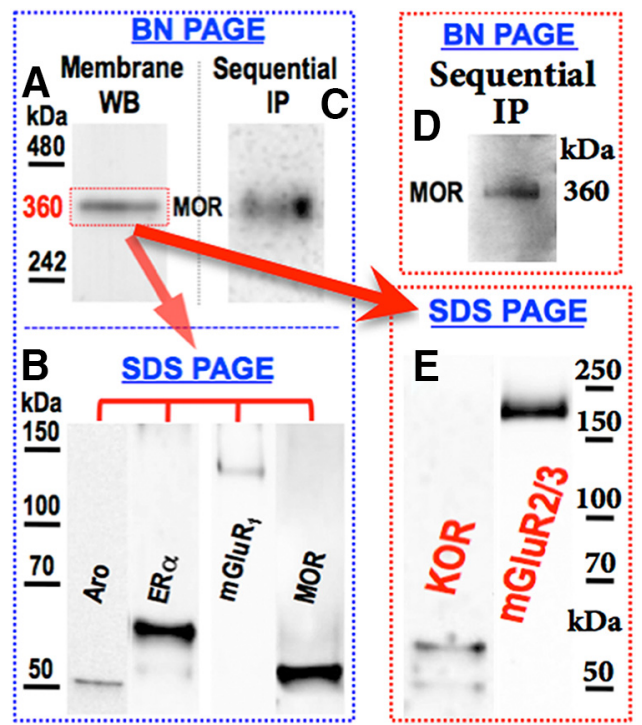

Figure 8. Spinal $K O R$ and $m G l u R_{2 / 3}$ are present in an oligomer containing MOR, $m G l u R_{1}$ $E R \alpha$, and aromatase. Solubilized spinal cord membranes were electrophoresed using blue native (BN) gels. $A, E, A \approx 360 \mathrm{kDa}$ band identified with Coomassie Blue $(\boldsymbol{A})$ was eluted and subjected to reducing SDS PAGE Western analysis using anti-KOR and anti-mGluR $\mathrm{R}_{2 / 3}$ antibodies (E). Since $\mathrm{mGluR}_{2 / 3}$ that coimmunoprecipitated with $\mathrm{mGluR}_{1}$ appeared at the predicted molecular mass $(\approx 110 \mathrm{kDa}$; Fig. 2$)$, its detected Western blot signal $(\approx 200 \mathrm{kDa}$ ) derived from the oligomer likely represents its dimerized form. $\boldsymbol{B}$, To validate the idea that the visualized KOR and mGluR $_{2 / 3}$ originated from the same oligomer as that previously shown to contain aromatase (Aro), ER $\alpha$, mGluR 1 , and MOR, solubilized spinal membranes were subjected to sequential IP using antibodies (in order) against Aro, ER $\alpha, \mathrm{mGluR}_{1}, \mathrm{KOR}$, and mGluR $\mathrm{R}_{2 / 3}$. C, D, MOR Western blotting of the final immunoprecipitate following $B N$ gel electrophoresis revealed $a \approx 360 \mathrm{kDa}$ band $(\boldsymbol{D})$, as was obtained when using the same procedure but absent IP with anti-KOR and anti-mGluR $2 / 3$ antibodies (C). A-C [previously reported (Liu et al., 2017), reproduced with permission from Pain) are included to integrate current findings with the previously defined oligomer. The discrepancy between the apparent molecular mass of the oligomer and the sum of its monomeric components ( $\approx 360 \mathrm{vs} \approx 450 \mathrm{kDa}$ ) likely results from the oligomer being resolved using nonreducing and nondenaturing conditions (BN PAGE), maintaining structure and charge density (shape, hydrodynamic diameter, and charge influence apparent molecular mass). In contrast, oligomer components were resolved using SDS-PAGE, eliminating threedimensional structure, making electrophoretic mobility dependent predominantly on size. Additionally, notwithstanding inaccuracies of molecular mass estimation using BN gels, summing apparent molecular mass of oligomer components resolved on SDS PAGE exacerbates the commonly accepted $10-15 \%$ variability of using this method for molecular mass estimation (Goetz et al., 2004).

essential for spinal EM2 antinociception during proestrus; Liu and Gintzler, 2013); (2) an analgesically effective dose of intrathecal EM2 inhibits spinal dynorphin release; (3) spinal dynorphin release in diestrus requires the activity of both $\mathrm{mER} \alpha$ and $\mathrm{mGluR}_{1}$ (providing a basis for their blockade to unmask EM2 antinociception in diestrus); and (4) in proestrus, glutamate activation of $\mathrm{mGluR}_{1}$ (together with $\mathrm{mGluR}_{2 / 3}$ ) promotes spinal EM2 analgesic responsiveness, notwithstanding that spinal EM2 antinociception is suppressed by $\mathrm{mGluR}_{1}$ during diestrus, when it is activated by $\operatorname{mER} \alpha$ [which is stimulated by spinal estrogens, whose production is inversely related to circulating estrogens (Liu et al., 2017)].

We previously reported that spinal dynorphin activation of KOR is a prerequisite for spinal EM2 antinociception in female rats (Liu and Gintzler, 2013). Current findings indicate that insufficient spinal dynorphin/KOR signaling is one basis for the absence of spinal EM2 analgesic responsiveness during diestrus. Multiple observations support this conclusion: (1) $\mathrm{mER} \alpha$ $\mathrm{mGluR}_{1}$ suppression of spinal EM2 antinociception results from their inhibition of spinal dynorphin release; (2) basal rates of 


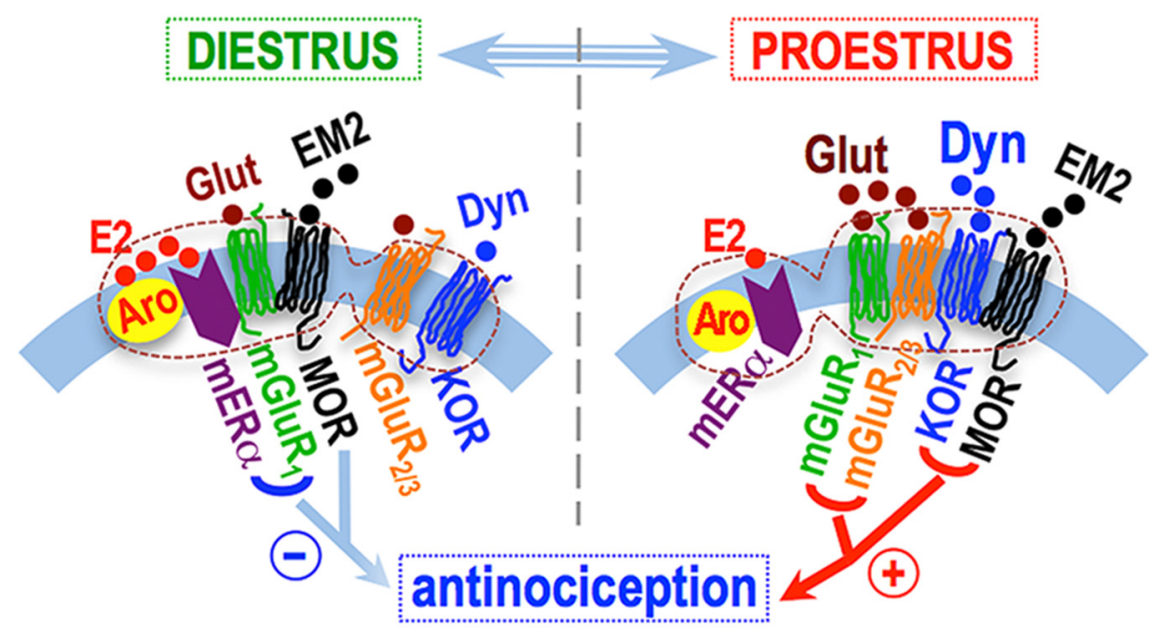

Figure 9. Schematic of fluid interactions within the described signaling oligomer, hypothesized to underlie estrous cycledependent analgesic responsiveness to intrathecal EM2. During diestrus, activation of $m E R-m G l u R_{1}$ signaling via estrogens (E2) synthesized within the oligomer (denoted by the dashed enclosure) suppresses analgesic responsiveness to intrathecal EM2 by inhibiting Dyn/KOR signaling. The emergence of spinal EM2 antinociception during proestrus results from (1) the disengagement of suppressive $m E R \alpha$ - $m G l u R_{1}$ signaling, (2) a shift from $m E R \alpha$ to glutamate activation of $\mathrm{mGluR}_{1}$, which now signals in collaboration with $\mathrm{mGluR}_{2 / 3}$, and (3) augmented spinal Dyn/KOR signaling. Our data are consistent with an organizational framework in which the spinal neurons coexpressing the relevant signaling proteins (oligomerized therein) are apposed by EM2-containing and glutamate-containing varicosities. This organization would enable individual neurons to vary responsiveness to EM2 as a function of the ebb and flow of spinal dynorphin and glutamate signaling over the estrous cycle.

spinal dynorphin release were $\approx 2$-fold higher during proestrus than diestrus, and (3) blockade of $\mathrm{mER} \alpha$ or $\mathrm{mGluR}_{1}$ during diestrus (which unmasks analgesic responsiveness to EM2) eliminated intrathecal EM2 inhibition of spinal dynorphin release. Thus, diestrus is associated with compromised functionality of the spinal dynorphin/KOR opioid system, which in turn reduces analgesic responsiveness to the spinal EM2/MOR opioid system. To the best of our knowledge, this is the first direct demonstration that minimizing one endogenous opioid system compromises another. Overall, our findings could underlie, at least in part, observations of variable nociception across the reproductive cycle (Teepker et al., 2010; Ibironke and Aji, 2011).

Paradoxically, $\mathrm{mGluR}_{1}$ signaling, which suppresses spinal EM2 antinociception during diestrus (Liu et al., 2017), is essential for EM2 antinociception during proestrus. Since in addition to glutamate, $\mathrm{mGluR}_{1}$ can also be activated by $\mathrm{mER} \alpha$ [presumably via protein-protein interactions (Dewing et al., 2007), which can be blocked by mGluR $_{1}$ antagonists (Boulware et al., 2005)], we hypothesized that the transition from negative to positive $\mathrm{mGluR}_{1}$ modulation of EM2 antinociception resulted from (1) a shift in the endogenous activator of $\mathrm{mGluR}_{1}$ from $\mathrm{mER} \alpha$ (during diestrus) to glutamate (during proestrus) and (2) the partnering of $\mathrm{mGluR}_{1}$ with $\mathrm{mGluR}_{2 / 3}$ (which are present in a common spinal oligomer). Both changes, individually and in combination, could alter downstream mGluR targets.

To test our hypothesis that $\mathrm{mGluR}_{1}$ activation by glutamate (instead of $m E R \alpha$ ) is critical to converting $\mathrm{mGluR}_{1}$ modulation of spinal EM2 antinociception from suppressive (during diestrus) to facilitative (during proestrus), we determined the effect of inhibiting endogenous release of glutamate on spinal EM2 antinociception during proestrus. Acute blockade of spinal glutamate release during proestrus substantially reduced EM2 analgesic responsiveness to that characteristic of diestrus (as did spinal $\mathrm{mGluR}_{1}$ blockade), supporting our formulation that the shift from spinal EM2 nonresponsive to analgesically responsive states results, at least in part, from opposing con- sequences of $\mathrm{mER} \alpha$-activated versus glutamate-activated $\mathrm{mGluR}_{1}$ signaling on EM2 antinociception (Fig. 9).

Suppression versus facilitation of spinal EM2 antinociception by mGluR $_{1}$ that depends on its activators suggests the importance of endogenous-biased agonism at $\mathrm{mGluR}_{1}$. Ligand bias refers to the propensity of agonists to activate or stabilize receptor conformations that preferentially stimulate specific signaling pathways. This is likely to be particularly relevant to $\mathrm{mGluR}_{1}$ signaling, since $\mathrm{mGluR}_{1}$ couples not only to $\mathrm{G}_{\mathrm{q}}$ (Masu et al., 1991), but also to $\mathrm{G}_{\mathrm{s}}$ (Aramori and Nakanishi, 1992; Miyashita and Kubo, 2000) and $\mathrm{G}_{\mathrm{i} / \mathrm{o}}$ (Akam et al., 1997; Sharon et al., 1997), the extent of which could be influenced by $\mathrm{mGluR}_{1}$ activation by $\mathrm{mER} \alpha$ versus glutamate. Our present finding that spinal EM2 antinociception is both inhibited and facilitated by spinal $\mathrm{mGluR}_{1}$, depending on its activator, strongly suggests that ligand bias pertains not only to exogenous agonists, but can also be an endogenous regulatory mechanism. Interestingly, in this regard, EM2 itself has been reported to be a biased agonist at MORs (McPherson et al., 2010; Rivero et al., 2012).

The contribution of the increased $\mathrm{mGluR}_{1}$ association with mGluR $_{2 / 3}$ to the ability of GGluR $_{1}$ to act as a switch, shifting from suppressing to facilitating EM2 antinociception, remains unknown. This notwithstanding, heterodimerization of G-protein-coupled receptors is known to alter the signaling of their monomeric form (AbdAlla et al., 2000; Chakrabarti et al., 2010). Interestingly, heterodimerization of $\mathrm{mGluR}_{1}$ with $\mathrm{GABA}_{\mathrm{B}}$ receptors increases the sensitivity of $\mathrm{mGluR}_{1}$ to glutamate (Tabata et al., 2002). Association of $\mathrm{mGluR}_{1}$ with mGluR $_{2 / 3}$ could similarly increase glutamate activation of $\mathrm{mGluR}_{1}$, thereby promoting the dissociation of $\operatorname{mER} \alpha$ from $\mathrm{mGluR}_{1}$ and thus the shift from $\mathrm{mER} \alpha-\mathrm{mGluR}_{1}$ suppression to glutamate- $\mathrm{mGluR}_{1}$ facilitation of spinal EM2 antinociception. Although decreasing glutamate release was able to block EM2 responsiveness during proestrus, it is not clear whether glutamate release is altered between proestrus and diestrus. It is possible that glutamate release onto spinal MOR neurons is suppressed by $\mathrm{mER} \alpha-\mathrm{mGluR}_{1}$ signaling during diestrus, which could be offset by the loss of such signaling during proestrus, analogous to modulation of dynorphin release over the estrous cycle.

The antinociception produced by EM2/MOR requires dynorphin, as well as the activity of MOR and KOR, both of which are present in a common oligomer along with aromatase, $\mathrm{mER} \alpha$, $\mathrm{mGluR}_{1}$, and $\mathrm{mGluR}_{2 / 3}$. Furthermore, during proestrus, MOR and KOR form a heterodimer, the MOR and KOR protomers of which can be occupied by EM2 and dynorphin, respectively. Interactions between $\mathrm{mGluR}_{1}$ and $\mathrm{mGluR}_{2 / 3}$, and their facilitation of MOR/KOR signal transduction would be aided by their presence in this common oligomer. Plasticity of interactions among components of the defined oligomer within a neuron receiving varying dynorphinergic and glutamatergic stimulation (inputs) represents a novel mechanism for modulating analgesic responsiveness to endogenous EM2. 
The relevance of current findings to spinal EM2 antinociception in males remains to be determined. Since spinal dynorphin/ KOR signaling does not contribute to EM2 antinociception in males (Liu and Gintzler, 2013), we expect the suppressive mER $\alpha$ $\mathrm{mGluR}_{1}$ regulatory pathway (which limits dynorphin release) to be absent from males. Additionally, if glutamate/ $\mathrm{mGluR}_{1}$ signaling is indeed essential for intrathecal EM2 antinociception in males, its contribution is highly unlikely to involve facilitation of KOR/MOR heterodimerization since levels of KOR/MOR heterodimers are much lower in males than in proestrus females. These differences underscore that mechanisms regulating spinal EM2 antinociception in males should not be extrapolated directly from females, but instead empirically determined.

The physiological trigger(s) for increasing responses to exogenous (intrathecal) EM2 could also be central to engaging endogenous EM2 antinociception. Our data (Liu et al., 2017; this study) show that spinal neurons in pain-processing regions coexpressing oligomer components (MOR, KOR, aromatase, $m E R \alpha, \mathrm{mGluR}_{1}$, and $\mathrm{mGluR}_{2 / 3}$ ) are also apposed by EM2-containing and glutamate-containing varicosities. Therefore, exogenous and endogenous spinal EM2 antinociception are likely modulated by common mechanisms.

The current prescription opioid abuse epidemic underscores the imperative for finding alternative pharmacotherapies for managing pain. The demonstration that endogenous opioids mediate placebo-induced antinociception (Levine et al., 1978; Zubieta et al., 2005; Wager et al., 2007) provides proof of concept of the potential utility of harnessing endogenous opioids for clinical pain relief. Although exogenously administered EM2 is not clinically relevant, it is a potent endogenous opioid. Our current finding that spinal EM2 antinociception is regulated over the estrous cycle by both the nature of the endogenous $\mathrm{mGluR}_{1}$ activator as well as changes in spinal dynorphin/KOR signaling could point the way for developing noncanonical pharmacological approaches to pain management that enable harnessing endogenous EM2 (and perhaps other endogenous opioids) for the sexspecific management of pain.

\section{References}

AbdAlla S, Lother H, Quitterer U (2000) AT1-receptor heterodimers show enhanced G-protein activation and altered receptor sequestration. Nature, 407:94-98. CrossRef

Acosta-Martinez M, Etgen AM (2002) Estrogen modulation of mu-opioid receptor-stimulated [35S]-GTP-gamma-S binding in female rat brain visualized by in vitro autoradiography. Neuroendocrinology 76:235-242. CrossRef Medline

Akam EC, Carruthers AM, Nahorski SR, Challiss RA (1997) Pharmacological characterization of type lalpha metabotropic glutamate receptorstimulated [35S]-GTPgammaS binding. Br J Pharmacol 121:1203-1209. CrossRef Medline

Alvarez FJ, Villalba RM, Carr PA, Grandes P, Somohano PM (2000) Differential distribution of metabotropic glutamate receptors $1 \mathrm{a}, 1 \mathrm{~b}$, and 5 in the rat spinal cord. J Comp Neurol 422:464-487. CrossRef Medline

Aramori I, Nakanishi S (1992) Signal transduction and pharmacological characteristics of a metabotropic glutamate receptor, mGluR1, in transfected CHO cells. Neuron 8:757-765. CrossRef Medline

Arvidsson U, Riedl M, Chakrabarti S, Vulchanova L, Lee JH, Nakano AH, Lin X, Loh HH, Law PY, Wessendorf MW (1995a) The kappa-opioid receptor is primarily postsynaptic: combined immunohistochemical localization of the receptor and endogenous opioids. Proc Natl Acad Sci U S A, 92:5062-5066. CrossRef Medline

Arvidsson U, Riedl M, Chakrabarti S, Lee JH, Nakano AH, Dado RJ, Loh HH, Law PY, Wessendorf MW, Elde R (1995b) Distribution and targeting of a $\mu$-opioid receptor (MOR1) in brain and spinal cord. J Neurosci 15:3328-3341. Medline

Beyer C, Pawlak J, Karolczak M (2003) Membrane receptors for oestrogen in the brain. J Neurochem 87:545-550. CrossRef Medline
Blaustein JD, Lehman MN, Turcotte JC, Greene G (1992) Estrogen receptors in dendrites and axon terminals in the guinea pig hypothalamus. Endocrinology 131:281-290. CrossRef Medline

Boulware MI, Weick JP, Becklund BR, Kuo SP, Groth RD, Mermelstein PG (2005) Estradiol activates group I and II metabotropic glutamate receptor signaling, leading to opposing influences on cAMP response elementbinding protein. J Neurosci 25:5066-5078. CrossRef Medline

Bradford MM (1976) A rapid and sensitive method for the quantitation of microgram quantities of protein utilizing the principle of protein-dye binding. Anal Biochem 72:248-254. CrossRef Medline

Chakrabarti S, Liu NJ, Gintzler AR (2010) Formation of mu-/kappa-opioid receptor heterodimer is sex-dependent and mediates female-specific opioid analgesia. Proc Natl Acad Sci U S A, 107:20115-20119. CrossRef Medline

Chalecka-Franaszek E, Weems HB, Crowder AT, Cox BM, Côté TE (2000) Immunoprecipitation of high-affinity, guanine nucleotide-sensitive, solubilized mu-opioid receptors from rat brain: coimmunoprecipitation of the $\mathrm{G}$ proteins $\mathrm{G}(\alpha \mathrm{o}), \mathrm{G}(\alpha \mathrm{i} 1)$, and $\mathrm{G}(\alpha \mathrm{i} 3)$. J Neurochem 74:1068-1078. CrossRef Medline

Cruz L, Basbaum AI (1985) Multiple opioid peptides and the modulation of pain: immunohistochemical analysis of dynorphin and enkephalin in the trigeminal nucleus caudalis and spinal cord of the cat. J Comp Neurol 240:331-348. CrossRef Medline

Dewing P, Boulware MI, Sinchak K, Christensen A, Mermelstein PG, Micevych P (2007) Membrane estrogen receptor- $\alpha$ interactions with metabotropic glutamate receptor la modulate female sexual receptivity in rats. J Neurosci 27:9294-9300. CrossRef Medline

Evrard HC (2006) Estrogen synthesis in the spinal dorsal horn: a new central mechanism for the hormonal regulation of pain. Am J Physiol Regul Integr Comp Physiol 291:R291-R299. CrossRef Medline

Evrard HC, Balthazart J (2004) Rapid regulation of pain by estrogens synthesized in spinal dorsal horn neurons. J Neurosci 24:7225-7229. CrossRef Medline

Evrard HC, Harada N, Balthazart J (2004) Immunocytochemical localization of aromatase in sensory and integrating nuclei of the hindbrain in Japanese quail (Coturnix japonica). J Comp Neurol 473:194-212. CrossRef Medline

Fillingim RB, King CD, Ribeiro-Dasilva MC, Rahim-Williams B, Riley JL 3rd (2009) Sex, gender, and pain: a review of recent clinical and experimental findings. J Pain 10:447-485. CrossRef Medline

Foidart A, Reid J, Absil P, Yoshimura N, Harada N, Balthazart J (1995) Critical re-examination of the distribution of aromatase-immunoreactive cells in the quail forebrain using antibodies raised against human placental aromatase and against the recombinant quail, mouse or human enzyme. J Chem Neuroanat 8:267-282. CrossRef Medline

Gintzler AR, Liu NJ (2012) Importance of sex to pain and its amelioration; relevance of spinal estrogens and its membrane receptors. Front Neuroendocrinol 33:412-424. CrossRef Medline

Gintzler AR, Schnell SA, Gupta DS, Liu NJ, Wessendorf MW (2008) Relationship of spinal dynorphin neurons to delta-opioid receptors and estrogen receptor alpha: anatomical basis for ovarian sex steroid opioid antinociception. J Pharmacol Exp Ther 326:725-731. CrossRef Medline

Goetz H, Kuschel M, Wulff T, Sauber C, Miller C, Fisher S, Woodward C (2004) Comparison of selected analytical techniques for protein sizing, quantitation and molecular weight determination. J Biochem Biophys Methods 60:281-293. CrossRef Medline

Hassan S, Muere A, Einstein G (2014) Ovarian hormones and chronic pain: a comprehensive review. Pain 155:2448-2460. CrossRef Medline

Hojo Y, Hattori TA, Enami T, Furukawa A, Suzuki K, Ishii HT, Mukai H, Morrison JH, Janssen WG, Kominami S, Harada N, Kimoto T, Kawato S (2004) Adult male rat hippocampus synthesizes estradiol from pregnenolone by cytochromes P45017alpha and P450 aromatase localized in neurons. Proc Natl Acad Sci U S A 101:865-870. CrossRef Medline

Horvath TL, Roa-Pena L, Jakab RL, Simpson ER, Naftolin F (1997) Aromatase in axonal processes of early postnatal hypothalamic and limbic areas including the cingulate cortex. J Steroid Biochem Mol Biol 61:349-357. CrossRef Medline

Ibironke GF, Aji KE (2011) Pain threshold variations in female rats as a function of the estrus cycle. Niger J Physiol Sci 26:67-70. Medline

Kumar A, Storman EM, Liu NJ, Gintzler AR (2015) Estrogens suppress spinal endomorphin 2 release in female rats in phase with the estrous cycle. Neuroendocrinology 102:33-43. CrossRef Medline 
Levine JD, Gordon NC, Jones RT, Fields HL (1978) The narcotic antagonist naloxone enhances clinical pain. Nature 272:826-827. CrossRef Medline

Liu NJ, Gintzler AR (2013) Spinal endomorphin 2 antinociception and the mechanisms that produce it are both sex- and stage of estrus cycledependent in rats. J Pain 14:1522-1530. CrossRef Medline

Liu NJ, Schnell SA, Schulz S, Wessendorf MW, Gintzler AR (2011a) Regulation of spinal dynorphin 1-17 release by endogenous pituitary adenylyl cyclase-activating polypeptide in the male rat: relevance of excitation via disinhibition. J Pharmacol Exp Ther 336:328-335. CrossRef Medline

Liu NJ, Chakrabarti S, Schnell S, Wessendorf M, Gintzler AR (2011b) Spinal synthesis of estrogen and concomitant signaling by membrane estrogen receptors regulate spinal $\kappa$ - and $\mu$-opioid receptor heterodimerization and female-specific spinal morphine antinociception. J Neurosci 31: 11836-11845. CrossRef Medline

Liu NJ, Schnell S, Wessendorf MW, Gintzler AR (2013) Sex, pain and opioids: inter-dependent influences of sex and pain modality on dynorphinmediated antinociception in rats. J Pharmacol Exp Ther 344:522-530. CrossRef Medline

Liu NJ, Murugaiyan V, Storman EM, Kumar A, Schnell SA, Wessendorf MW, Gintzler AR (2017) Estrogens synthesized and acting within a spinal oligomer suppress spinal endomorphin 2 antinociception: ebb and flow over the reproductive cycle. Pain 158:1903-1914. CrossRef Medline

Loyd DR, Murphy AZ. (2014) The neuroanatomy of sexual dimorphism in opioid analgesia. Exp Neurol 259:57-63. CrossRef Medline

Mao J, Sung B, Ji RR, Lim G (2002) Chronic morphine induces downregulation of spinal glutamate transporters: implications in morphine tolerance and abnormal pain sensitivity. J Neurosci 22:8312-8323. Medline

Masu M, Tanabe Y, Tsuchida K, Shigemoto R, Nakanishi S (1991) Sequence and expression of a metabotropic glutamate receptor. Nature 349:760765. CrossRef Medline

Maurer AJ, Lissounov A, Knezevic I, Candido KD, Knezevic NN (2016) Pain and sex hormones: a review of current understanding. Pain Manag 6:285-296. CrossRef Medline

McEwen BS, Alves SE (1999) Estrogen actions in the central nervous system. Endocr Rev 20:279-307. CrossRef Medline

McEwen B, Akama K, Alves S, Brake WG, Bulloch K, Lee S, Li C, Yuen G, Milner TA (2001) Tracking the estrogen receptor in neurons: implications for estrogen-induced synapse formation. Proc Natl Acad Sci U S A 98:7093-7100. CrossRef Medline

McPherson J, Rivero G, Baptist M, Llorente J, Al-Sabah S, Krasel C, Dewey WL, Bailey CP, Rosethorne EM, Charlton SJ, Henderson G, Kelly E (2010) mu-Opioid receptors: correlation of agonist efficacy for signalling with ability to activate internalization. Mol Pharmacol 78:756-766. CrossRef Medline

Micevych PE, Rissman EF, Gustafsson JA, Sinchak K (2003) Estrogen receptor-alpha is required for estrogen-induced mu-opioid receptor internalization. J Neurosci Res 71:802-810. CrossRef Medline

Miller KE, Seybold VS (1989) Comparison of met-enkephalin, dynorphin $\mathrm{A}$, and neurotensin immunoreactive neurons in the cat and rat spinal cords: II. Segmental differences in the marginal zone. J Comp Neurol 279:619-628. CrossRef Medline

Miyashita T, Kubo Y (2000) Extracellular Ca2 + sensitivity of mGluR1alpha induces an increase in the basal cAMP level by direct coupling with Gs protein in transfected CHO cells. Receptors Channels 7:77-91. Medline

Mogil JS, Chesler EJ, Wilson SG, Juraska JM, Sternberg WF (2000) Sex differences in thermal nociception and morphine antinociception in rodents depend on genotype. Neurosci Biobehav Rev 24:375-389. CrossRef Medline

Naftolin F, Horvath TL, Jakab RL, Leranth C, Harada N, Balthazart J (1996) Aromatase immunoreactivity in axon terminals of the vertebrate brain. An immunocytochemical study on quail, rat, monkey and human tissues. Neuroendocrinology 63:149-155. Medline

Papka RE, Storey-Workley M, Shughrue PJ, Merchenthaler I, Collins JJ, Usip S, Saunders PT, Shupnik M (2001) Estrogen receptor-alpha and beta- immunoreactivity and mRNA in neurons of sensory and autonomic ganglia and spinal cord. Cell Tissue Res 304:193-214. CrossRef Medline

Peterson RS, Yarram L, Schlinger BA, Saldanha CJ (2005) Aromatase is presynaptic and sexually dimorphic in the adult zebra finch brain. Proc Biol Sci 272:2089-2096. CrossRef Medline

Rivero G, Llorente J, McPherson J, Cooke A, Mundell SJ, McArdle CA, Rosethorne EM, Charlton SJ, Krasel C, Bailey CP, Henderson G, Kelly E (2012) Endomorphin-2: a biased agonist at the mu-opioid receptor. Mol Pharmacol 82:178-188. CrossRef Medline

Saldanha CJ, Tuerk MJ, Kim YH, Fernandes AO, Arnold AP, Schlinger BA (2000) Distribution and regulation of telencephalic aromatase expression in the zebra finch revealed with a specific antibody. J Comp Neurol 423:619-630. CrossRef Medline

Saldanha CJ, Remage-Healey L, Schlinger BA (2011) Synaptocrine signaling: steroid synthesis and action at the synapse. Endocr Rev 32:532-549. CrossRef Medline

Schägger H, von Jagow G (1991) Blue native electrophoresis for isolation of membrane protein complexes in enzymatically active form. Anal Biochem 199:223-231. CrossRef Medline

Sharon D, Vorobiov D, Dascal N (1997) Positive and negative coupling of the metabotropic glutamate receptors to a $\mathrm{G}$ protein-activated $\mathrm{K}+$ channel, GIRK, in Xenopus oocytes. J Gen Physiol 109:477-490. CrossRef Medline

Shim WS, DiRenzo J, DeCaprio JA, Santen RJ, Brown M, Jeng MH (1999) Segregation of steroid receptor coactivator-1 from steroid receptors in mammary epithelium. Proc Natl Acad Sci U S A 96:208-213. CrossRef Medline

Shughrue PJ, Lane MV, Merchenthaler I (1997) Comparative distribution of estrogen receptor-alpha and -beta mRNA in the rat central nervous system. J Comp Neurol 388:507-525. CrossRef Medline

Smith YR, Stohler CS, Nichols TE, Bueller JA, Koeppe RA, Zubieta JK (2006) Pronociceptive and antinociceptive effects of estradiol through endogenous opioid neurotransmission in women. J Neurosci 26:5777-5785. CrossRef Medline

Sung B, Lim G, Mao J (2003) Altered expression and uptake activity of spinal glutamate transporters after nerve injury contribute to the pathogenesis of neuropathic pain in rats. J Neurosci 23:2899-2910. Medline

Sweetnam PM, Wrathall JR, Neale JH (1986) Localization of dynorphin gene product-immunoreactivity in neurons from spinal cord and dorsal root ganglia. Neuroscience 18:947-955. CrossRef Medline

Tabata T, Aiba A, Kano M (2002) Extracellular calcium controls the dynamic range of neuronal metabotropic glutamate receptor responses. Mol Cell Neurosci 20:56-68. CrossRef Medline

Tang FR, Sim MK (1999) Pre- and/or post-synaptic localisation of metabotropic glutamate receptor 1alpha (mGluR1alpha) and $2 / 3$ (mGluR2/3) in the rat spinal cord. Neurosci Res 34:73-78. CrossRef Medline

Teepker M, Peters M, Vedder H, Schepelmann K, Lautenbacher S (2010) Menstrual variation in experimental pain: correlation with gonadal hormones. Neuropsychobiology 61:131-140. CrossRef Medline

Wager TD, Scott DJ, Zubieta JK (2007) Placebo effects on human muopioid activity during pain. Proc Natl Acad Sci U S A 104:11056-11061. CrossRef Medline

Williams SJ, Papka RE (1996) Estrogen receptor-immunoreactive neurons are present in the female rat lumbosacral spinal cord. J Neurosci Res 46:492-501. CrossRef Medline

Yung KK (1998) Localization of glutamate receptors in dorsal horn of rat spinal cord. Neuroreport 9:1639-1644. CrossRef Medline

Zeps N, Bentel JM, Papadimitriou JM, D’Antuono MF, Dawkins HJ (1998) Estrogen receptor-negative epithelial cells in mouse mammary gland development and growth. Differentiation 62:221-226. CrossRef Medline

Zubieta JK, Bueller JA, Jackson LR, Scott DJ, Xu Y, Koeppe RA, Nichols TE, Stohler CS (2005) Placebo effects mediated by endogenous opioid activity on $\mu$-opioid receptors. J Neurosci 25:7754-7762. CrossRef Medline 